\title{
The Contribution of Cytomegalovirus Infection to Immune Senescence Is Set by the Infectious Dose
}

\section{OPEN ACCESS}

Edited by:

Francesca Di Rosa,

Institute of Molecular Biology

and Pathology (CNR), Italy

Reviewed by:

Paul Austin Moss,

University of Birmingham,

United Kingdom

Tania H. Watts,

University of Toronto, Canada

${ }^{*}$ Correspondence:

Ramon Arens

R.Arens@/umc.nl

${ }^{+}$Present address:

Suzanne P. M. Welten,

Department of Biology, Swiss Federal Institute of Technology,

Zurich, Switzerland

\#These authors have contributed equally to this work.

Specialty section:

This article was submitted to Immunological Memory,

a section of the journal

Frontiers in Immunology

Received: 19 October 2017 Accepted: 18 December 2017

Published: 10 January 2018

Citation:

Redeker A, Remmerswaal EBM, van der Gracht ETI, Welten SPM,

Höllt T, Koning F, Cicin-Sain L,

Nikolich-Žugich J, ten Berge IJM,

van Lier RAW, van Unen V and Arens $R$ (2018) The Contribution

of Cytomegalovirus Infection

to Immune Senescence Is Set

by the Infectious Dose.

Front. Immunol. 8:1953. doi: 10.3389/fimmu.2017.01953

\author{
Anke Redeker', Ester B. M. Remmerswaal2,3ł, Esmé T. I. van der Gracht ${ }^{1 \neq}$, \\ Suzanne P. M. Welten ${ }^{1 \dagger}$, Thomas Höllt', Frits Koning ${ }^{1}$, Luka Cicin-Sain ${ }^{5}$, \\ Janko Nikolich-Žugich ${ }^{6}$, Ineke J. M. ten Berge ${ }^{2,3}$, René A. W. van Lier', \\ Vincent van Unen ${ }^{1}$ and Ramon Arens ${ }^{1 *}$
}

${ }^{1}$ Department of Immunohematology and Blood Transfusion, Leiden University Medical Center, Leiden, Netherlands, ${ }^{2}$ Department of Experimental Immunology, Academic Medical Center, Amsterdam, Netherlands, ${ }^{3}$ Renal Transplant Unit, Division of Internal Medicine, Academic Medical Center, Amsterdam, Netherlands, ${ }^{4}$ Delft University of Technology, Delft, Netherlands, ${ }^{5}$ Helmholtz Centre for Infection Research, Braunschweig, Germany, ${ }^{6}$ Department of Immunobiology, University of Arizona College of Medicine, Tucson, AZ, United States, ${ }^{7}$ Sanquin Blood Supply Foundation and Landsteiner Laboratory, Amsterdam, Netherlands

The relationship between human cytomegalovirus (HCMV) infections and accelerated immune senescence is controversial. Whereas some studies reported a CMV-associated impaired capacity to control heterologous infections at old age, other studies could not confirm this. We hypothesized that these discrepancies might relate to the variability in the infectious dose of CMV occurring in real life. Here, we investigated the influence of persistent CMV infection on immune perturbations and specifically addressed the role of the infectious dose on the contribution of CMV to accelerated immune senescence. We show in experimental mouse models that the degree of mouse CMV (MCMV)-specific memory $\mathrm{CD}^{+} \mathrm{T}$ cell accumulation and the phenotypic $\mathrm{T}$ cell profile are directly influenced by the infectious dose, and data on HCMV-specific T cells indicate a similar connection. Detailed cluster analysis of the memory $\mathrm{CD}^{+} \mathrm{T}$ cell development showed that high-dose infection causes a differentiation pathway that progresses faster throughout the life span of the host, suggesting a virus-host balance that is influenced by aging and infectious dose. Importantly, short-term MCMV infection in adult mice is not disadvantageous for heterologous superinfection with lymphocytic choriomeningitis virus (LCMV). However, following long-term CMV infection the strength of the CD8 ${ }^{+} \mathrm{T}$ cell immunity to LCMV superinfection was affected by the initial CMV infectious dose, wherein a high infectious dose was found to be a prerequisite for impaired heterologous immunity. Altogether our results underscore the importance of stratification based on the size and differentiation of the CMV-specific memory $T$ cell pools for the impact on immune senescence, and indicate that reduction of the latent/lytic viral load can be beneficial to diminish CMV-associated immune senescence.

Keywords: CMV, memory CD8 T cells, immunesenesence, mouse models, memory inflation

\section{INTRODUCTION}

Age-related decline in immunological competence, often referred to as immune senescence, is associated with an increased incidence of cancer, infections, and a reduced efficacy of vaccines (1). Factors thought to contribute to this progressive decline of immune responses include genetic, molecular, and cellular defects, but also environmental stressors such as chronic infections. 
Human cytomegalovirus (HCMV), a member of the betaherpesvirus family, persists in the majority of the adult population (2). Compared to other infections, extraordinary high memory $\mathrm{T}$ cell frequencies, on average $\sim 10 \%$ of the total memory $\mathrm{T}$ cell compartment, are noticed in peripheral blood of healthy individuals (3). Especially at old age, it has been observed that the HCMV-specific memory T cell pool can even occupy up to $50 \%$ of the total memory compartment (4). This phenomenon of high frequencies of circulating memory $\mathrm{T}$ cells that are maintained during the lifespan of the host or even can undergo gradual increment, aptly named memory inflation (5), is characteristic of CMV infection in general, as this is also found upon infection with the related mouse CMV (MCMV) and Rhesus Macaque CMV (RhCMV) [reviewed in Ref. $(6,7)$ ]. The inflationary $\mathrm{T}$ cells, which increase in numbers during the persistent phase of infection, are phenotypically characterized by an "effectormemory (EM)"-like appearance (CD27 low $/ \mathrm{CD}^{2} \mathrm{~L}^{\text {low }} / \mathrm{CD} 127^{-} /$ $\mathrm{KLRG1}^{+}$; e.g., the $\mathrm{CD} 8^{+} \mathrm{T}$ cell response against the $\mathrm{m} 139_{419-426}$, M38 ${ }_{316-323}$, IE $3_{416-423}$ epitopes in MCMV). During CMV infection, T cells with a central-memory phenotype also exist (CD27 high/ $\mathrm{CD}_{2} \mathrm{~L}^{\text {high }} / \mathrm{CD} 127^{+}$), which peak early during infection, contract, and establish stable memory pools (e.g., the CD8 ${ }^{+} \mathrm{T}$ cell response against the M45 ${ }_{985-993}$ epitope in MCMV). The occurrence of inflationary $\mathrm{T}$ cell responses is reliant on the intermittent transcription of CMV during latency resulting in antigen reactivation (8). In addition, the efficacy of peptide processing by the constitutive proteasome is an important determinant for memory inflation (9).

Epidemiological studies have shown an association between HCMV positivity and manifestations of immune senescence by linking persistent HCMV infection to decreased overall survival in the elderly and to the immune risk profile (IRP), a cluster of parameters predictive for 2-year mortality in the elderly $(10,11)$. In addition, anti-HCMV IgG titers in aged individuals have been correlated with lower antibody responses to influenza (12-15); however, other studies could not confirm this finding (16-19). Thus, whether HCMV infection is causally linked with accelerated immune senescence is a topic of debate $(20,21)$.

To gain more insight into the possible connection between CMV infection and immune senescence, mouse studies have been performed previously in which it was demonstrated that long-term CMV infection impairs newly generated CD8 ${ }^{+} \mathrm{T}$ cell responses to heterologous infections (22-24). However, these studies have been conducted using relatively high doses of virus, and have not taken into account the variability in real life with respect to the infectious dose. For example, in the human population the percentages of CMV-specific T cells occupying the memory $\mathrm{T}$ cell compartment is highly variable (ranging from 0.01 to $50 \%$ ) (3), which is likely related to the significant difference in the quantity of CMV found in bodily fluids, such as breast milk, saliva, and urine $\left(10^{1}-10^{5}\right.$ copies/ $\left.\mu \mathrm{l}\right)$, causing horizontal transmission of CMV $(25,26)$. In this respect, we have previously shown that the degree of accumulation and phenotype of inflationary CMV-specific CD8 ${ }^{+} \mathrm{T}$ cells is corresponding to the size of the initial infectious dose (27).
We anticipate that the viral inoculum size is highly variable between individuals and that this accounts for the large variance in the frequency, phenotype, and accumulation of CMV-specific $\mathrm{CD}^{+}$memory $\mathrm{T}$ cells in infected humans, which may be an explanation for the controversial results with respect to the possible contribution of CMV to immune senescence. Here, we tested this hypothesis in a highly controlled prospective study using the mouse model of CMV infection, which mimics CMV infection in humans (28). We inoculated mice with different inoculum dosages of MCMV and investigated longitudinally the influence of lifelong CMV infection on alterations within the peripheral $\mathrm{T}$ cell pool. To specifically assess the role of the CMV inoculum size on the development of heterologous anti-viral immunity, aged MCMV-infected mice received a challenge with lymphocytic choriomeningitis virus (LCMV). Our results show that the viral inoculum size determines the degree of CMV-induced immune alterations in lifelong infection. Furthermore, we demonstrate that only infection caused by a high MCMV dose reduces newly generated $\mathrm{CD}^{+} \mathrm{T}$ cell responses to heterologous superinfection. To our knowledge, this is the first evidence that the inoculum size of CMV is a crucial determinant for the development of CMVassociated impaired immunity in aging.

\section{MATERIALS AND METHODS}

\section{Mice}

Wild-type (WT) C57BL/6 mice were purchased from Charles River. All mice were maintained under specific pathogen-free conditions at the Central Animal Facility of LUMC. Mice were housed under $12 \mathrm{~h}$ light/dark cycle, feed ad libitum and were 7-10 weeks old at the beginning of each experiment.

\section{Viruses}

Mouse CMV-Smith was obtained from the American Type Culture Collection (ATCC VR-194; Manassas, VA, USA) and salivary gland stocks were prepared from infected BALB/c mice. WT mice matched for gender and age were infected i.p. with indicated dosages of salivary gland derived MCMV-Smith. For weekly infections with MCMV mice received $5 \times 10^{4} \mathrm{PFU}$ MCMV weekly for 1 year. Vaccinia virus expressing IE1 of MCMV (VACV-IE1) was produced as described elsewhere (29). BALB/c $\times$ DBA/2 F1 mice were infected with $1 \times 10^{6} \mathrm{PFU}$ (VACV-IE1) as described (23). LCMV-Armstrong was propagated on BHK cells and titers of virus stocks and organ homogenates were determined by plaque assays on Vero cells as described. For LCMV-Armstrong infection, WT mice (uninfected and previously infected with MCMV) were infected i.p. with $2 \times 10^{5}$ PFU. LCMV titers in the lungs and kidneys were determined by a virus focus forming assay on Vero 76 cells as described elsewhere (30).

\section{Study Subjects}

For phenotypical analysis of HCMV-specific T cell responses, PBMCs from HCMV-seropositive healthy donors and from initially $\mathrm{HCMV}$-seronegative recipients (HLA-A ${ }^{\star} 0101^{+}$, HLA$\mathrm{A}^{\star} 0201^{+}, \mathrm{HLA}-\mathrm{B}^{\star} 0702^{+}$, HLA-B ${ }^{\star} 3501^{+}$) receiving a $\mathrm{HCMV}$ positive kidney transplant were isolated and labeled for flow 
cytometry analysis (31). Quantitative PCR for HCMV was performed in EDTA-treated whole-blood samples, as described elsewhere (32).

\section{Flow Cytometry}

MHC class I tetramer staining combined with phenotyping, and intracellular cytokine staining were performed to determine the magnitude and characteristics of the mouse viral-specific $\mathrm{T}$ cell responses as described (33). Single-cell suspensions were prepared from spleens obtained from uninfected and infected mice by mincing the tissue through a $70-\mu \mathrm{m}$ cell strainer (BD Bioscience). Blood was collected from the tail vein. Erythrocytes were lysed in a hypotonic ammonium chloride buffer. Fluorochromeconjugated antibodies specific for mouse CD3, CD4, CD8, CD27, CD44, CD62L, CD127 (IL-7R $\alpha$ ), IFN- $\gamma$, IL-2, KLRG1, and TNF were purchased from BD Biosciences, Biolegend, or eBioscience. Analysis of human PBMCs was performed as described (31). Fluorochrome-conjugated antibodies specific for human CCR7, CD3, CD8, CD27, CD28, CD45RA, CD57, CD127, and KLRG1 were purchased from BD Biosciences, Biolegend, or eBioscience. Cells were acquired using a BD LSR Fortessa flow cytometer, and data were analyzed using FlowJo software (TreeStar) and Cytosplore (34). Dead cells were excluded using live/dead markers. Gating strategies were performed as described (27, 31).

\section{MHC Class I Tetramers and Synthetic Peptides}

The following class I-restricted peptides were used: M45985-993, m139 ${ }_{419-426}, \mathrm{M}_{38_{316-323}}, \mathrm{IE} 3_{416-423}, \mathrm{IE} 1_{168-176}$ (MCMV), GP33 $33-41$, $\mathrm{NP}_{396-404}, \mathrm{GP}_{276-286}$ (LCMV). A pool of the following class II-restricted MCMV peptides were used: M09 $9_{133-147}$, M25 $5_{409-423}$, $\mathrm{m} 139_{560-574}$, and $\mathrm{m} 142_{24-38}$ (35). The following class II-restricted LCMV peptide was used: GP $61-80$. APC and PE-labeled MHC class I tetrameric complexes with the above-described peptide epitopes were used. For analysis of $\mathrm{HCMV}$-specific $\mathrm{CD}^{+} \mathrm{T}$ cell responses, MHC class I tetrameric complexes with the following peptides were used: pp65 $5_{363-373}\left(\right.$ HLA-A $\left.{ }^{\star} 0101\right)$, pp65 $_{495-503}($ HLA-A*0201), pp65 ${ }_{417-426}\left(\mathrm{HLA}^{\star} \mathrm{B}^{\star} 0702\right)$, pp65 ${ }_{123-131}\left(\mathrm{HLA}-\mathrm{B}^{\star 3501)}\right.$.

\section{Multiplex}

Blood was collected retro-orbitally and clotted for $30 \mathrm{~min}$. After centrifugation, serum was collected and stored at $-80^{\circ} \mathrm{C}$ until further use. Cytokines were measured in serum using a mouse Bio-Plex Pro Mouse Cytokine 23-plex immunoassay (Bio-Rad, Herculus, CA, USA) according to manufacturer's protocol.

\section{Serum Antibody Detection by ELISA}

Total IgM and IgG concentrations were determined by ELISA in serum samples as described earlier (27). Briefly, Nunc-Immuno Maxisorp plates (Fisher Scientific) were coated overnight with virus in bicarbonate buffer, and after blocking (skim milk powder, Fluka BioChemika), sera from mice were added. Next, plates were incubated with various HRP-conjugated antibodies (SouthernBiotech) to detect IgM/IgG. Plates were developed with TMB substrate (Sigma Aldrich), and the color reaction was stopped by the addition of $1 \mathrm{M} \mathrm{H}_{2} \mathrm{SO}_{4}$. Optical density was read at $450 \mathrm{~nm}\left(\mathrm{OD}_{450}\right)$ using a Microplate reader (Model 680, Bio-Rad).

\section{Statistical Analysis}

To determine statistical significance between two groups, an unpaired Student's $t$-test was performed. Significance between more than two groups was evaluated by one-way ANOVA and Tukey's post hoc test was performed to correct for multiple comparisons. Mann-Whitney $U$ test and Kruskal-Wallis test were performed to determine statistical differences in the viral load in mice. To test the strength of the linear relationship between the frequency of EM CD8 ${ }^{+}$T cells and the LCMV viral load, Pearson correlation was used. For correlations between the frequency of EM CD8 ${ }^{+} \mathrm{T}$ cells and the magnitude of the response, Spearman correlation was used. GraphPad Prism 6.0 software (GraphPad Software, La Jolla, CA, USA) was used for statistical analyses.

\section{RESULTS}

\section{Disparate Effects of CMV Infection and Aging on Naive and Memory CD8 ${ }^{+}$ and $\mathrm{CD4}^{+} \mathrm{T}$ Cell Subsets}

To investigate whether dissimilar infectious dosages of MCMV differentially affect the immune system in lifelong infection, we inoculated C57BL/ 6 mice at 7 weeks of age with different dosages of MCMV-Smith $\left(0,10^{3}, 10^{4}\right.$, and $\left.10^{5} \mathrm{PFU}\right)$ and monitored the $\mathrm{CD}^{+}$and $\mathrm{CD}^{+} \mathrm{T}$ cell frequencies over 300 days post-infection (dpi). In naive (uninfected) mice, the frequency of total peripheral $\mathrm{CD}^{+} \mathrm{T}$ cells was unchanged in time. However, early after MCMV infection (acute phase), $\mathrm{CD}^{+} \mathrm{T}$ cell frequencies were elevated corresponding to the inoculum size (Figure 1A). A strict impact of the inoculum size was also observed at later time points: mice that were infected with the highest MCMV PFU quantities showed the highest frequency of $\mathrm{CD} 8^{+} \mathrm{T}$ cells. Only mice infected with the lowest inoculum dose $\left(10^{3} \mathrm{PFU}\right)$ did not differ substantially during the persistent phase from naive agematched controls (Figure 1A). The frequency of total peripheral $\mathrm{CD}^{+} \mathrm{T}$ cells in naive and infected mice showed an age-related decrease, yet effects of the dosage of MCMV infection were not apparent for this $\mathrm{T}$ cell subset (Figure 1A).

It has been suggested that HCMV-seropositivity is linked to the IRP and one of the parameters defining the IRP is an inverted CD4/CD8 $\mathrm{T}$ cell ratio (36). Moreover, it has been shown that latent MCMV infection decreases this ratio (23). By calculating, the CD4/CD8 $\mathrm{T}$ cell ratio, we also observed a decreased CD4/ CD8 $\mathrm{T}$ cell ratio during the persistent phase and markedly noticed an obvious MCMV-dose impact for this phenomenon (Figure 1B). A decreased CD4/CD8 $\mathrm{T}$ cell ratio was also most apparent in high-dose-infected aged mice based on the absolute counts of $\mathrm{CD}^{+}$and $\mathrm{CD} 4^{+} \mathrm{T}$ cells present in the spleen, and this was mainly caused by an increment of the absolute $\mathrm{CD}^{+} \mathrm{T}$ cell count (Figure S1A in Supplementary Material).

Next, we assessed the influence of the different MCMV inoculum sizes on the naive and memory $\mathrm{T}$ cell subset composition during the course of infection. MCMV infection resulted in 


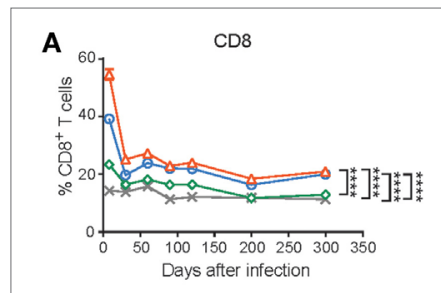

D

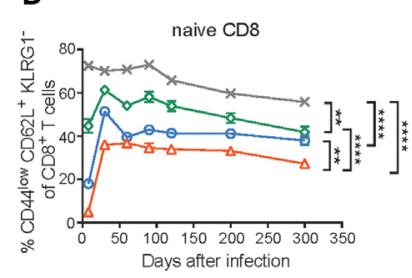

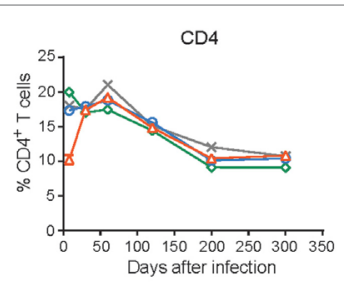
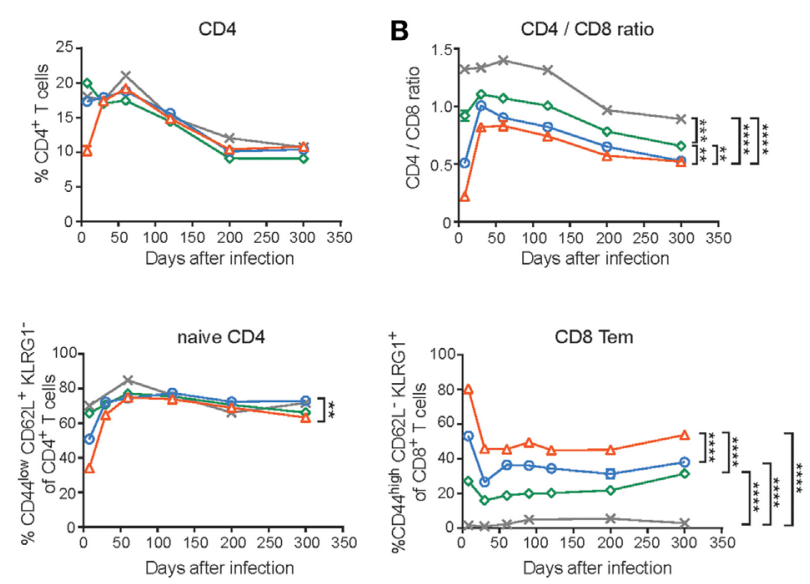
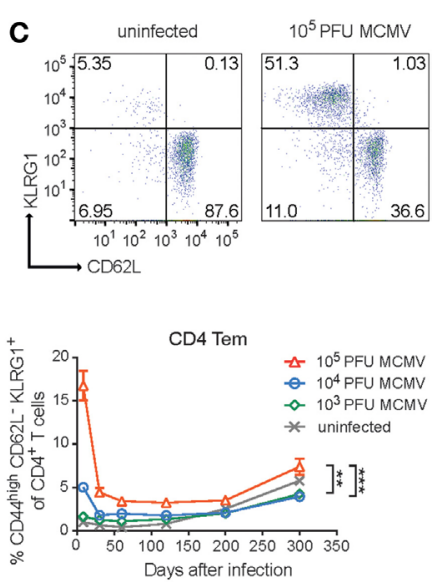

FIGURE 1 | Disparate effects of CMV infection and aging on naive and memory CD8 ${ }^{+}$and $\mathrm{CD}^{+} \mathrm{T}$ cell subsets. Wild-type $(\mathrm{WT})$ mice were infected with $10^{3}$, $10^{4}$, or $10^{5}$ PFU mouse CMV (MCMV)-Smith. (A) The average frequencies of CD8 ${ }^{+}$and CD4 ${ }^{+} \mathrm{T}$ cells in blood determined at the indicated time points post-infection. (B) The $\mathrm{CD}^{+} / \mathrm{CD} 8^{+} \mathrm{T}$ cell ratio in blood determined at the indicated time points. (C) Representative flow cytometry plots showing the KLRG1 versus CD62L expression on $\mathrm{CD}^{+} \mathrm{T}$ cells of naive and $10^{5} \mathrm{PFU}$ MCMV-infected mice. (D) Kinetic analysis of the average frequencies of naive (CD44 $\left.{ }^{\text {low }} \mathrm{CD} 6 \mathrm{~L}^{+} \mathrm{KLRG} 1^{-}\right)$or effector-memory (Tem) $\left(\mathrm{CD} 44^{\text {high }} \mathrm{CD62} \mathrm{L}^{-} \mathrm{KLRG1} 1^{+}\right) \mathrm{CD}^{+}$and $\mathrm{CD} 4^{+} \mathrm{T}$ cells in blood. Error bars indicate SEM ( $n=16$ mice per group). Significance is indicated for day 300 post-infection. $\left({ }^{\star} P<0.05 ;{ }^{\star \star} P<0.01 ;{ }^{\star \star \star} P<0.001 ;{ }^{\star \star \star \star} P<0.0001\right)$. Data were pooled from two independent experiments.

strongly reduced frequencies of naive circulating $\mathrm{CD} 8^{+} \mathrm{T}$ cells $\left(\mathrm{CD} 44^{\text {low }} \mathrm{CD} 2 \mathrm{~L}^{+} \mathrm{KLRG}^{-}\right)$, which inversely correlated with the inoculum dose (Figures 1C,D). Aging reduced the naive CD8 ${ }^{+}$ $\mathrm{T}$ cell frequencies in both uninfected and infected mice. The differences between the groups of differently MCMV dosage inoculated mice remained over time. The naive $\mathrm{CD}^{+} \mathrm{T}$ cell pool was not overtly influenced by the inoculum size or aging (Figure 1D).

Accumulation of EM (CD44 $\left.4^{\text {high }} \mathrm{CD} 62 \mathrm{~L}^{-} \mathrm{KLRG}^{+}\right) \mathrm{CD}^{+}$ $\mathrm{T}$ cells was not observed in uninfected animals. However, this was clearly present after MCMV infection. Strikingly, increasing inoculum sizes correspondingly heightened the frequency of EM $\mathrm{CD}^{+} \mathrm{T}$ cells. These differences in $\mathrm{EM} \mathrm{CD} 8^{+} \mathrm{T}$ cell frequency between the groups remained stable during persistent infection and somewhat inclined after $200 \mathrm{dpi}$ (Figure 1D). The EM CD $4^{+}$ $\mathrm{T}$ cell frequencies were increased after the highest dose inoculum and remained higher compared to lower dose infected mice and uninfected mice (Figure 1D). Aging increased the EM CD4 ${ }^{+}$ $\mathrm{T}$ cell frequency in both infected and uninfected mice after 200 dpi. Thus, the size of the MCMV inoculum predominantly affects the formation of EM-like $\mathrm{CD}^{+} \mathrm{T}$ cells throughout the course of infection while aging seems to predominantly impact the percentages of EM-like $\mathrm{CD} 4^{+} \mathrm{T}$ cells.

\section{The Magnitude and Phenotype of Inflationary MCMV-Specific CD8 ${ }^{+}$ T Cells Is Strongly Influenced by the Inoculum Dose}

Next, we determined if dissimilarities in inoculum dosage sizes would differentially affect MCMV-specific $\mathrm{CD}^{+} \mathrm{T}$ cell populations during aging. In the acute phase of infection, we observed that the magnitude of both non-inflationary (M45-specific) and inflationary (m139-, M38-, and IE3-specific) MCMV-specific
$\mathrm{CD}^{+} \mathrm{T}$ cell responses were correspondingly $\sim 2$-fold higher in the group infected with a 10 -fold higher dose. During the chronic phase of infection, the frequency of the M45-specific CD8 ${ }^{+}$ $\mathrm{T}$ cells is comparable between the different inoculum sizes. By contrast, the magnitude of the $\mathrm{CD}^{+} \mathrm{T}$ cell response against the inflationary epitopes in $\mathrm{m} 139, \mathrm{M} 38$, and IE3 increased in a strict dose-dependent manner (Figure 2A).

Induction of MCMV-associated immune senescence may be potentiated by the accumulation of virus-specific EM-like $\mathrm{CD} 8^{+}$ $\mathrm{T}$ cells. Here, we assessed the phenotype of the antigen-specific $\mathrm{CD}^{+} \mathrm{T}$ cells that were induced after inoculation with the different MCMV doses. For all MCMV-specific CD ${ }^{+} \mathrm{T}$ cell responses measured, we observed that the size of the viral inoculum determines the frequency of effector $\mathrm{CD}^{+} \mathrm{T}$ cells during the acute phase (Figure 2B). While the effector phenotypic profile of the non-inflationary M45-specific T cells is gradually turned into a predominant central-memory $\left(\mathrm{CM}\right.$; $\mathrm{CD} 44^{\text {high }} \mathrm{CD} 62 \mathrm{~L}^{+}$ $\mathrm{KLRG1}^{-}$) phenotype, the $\mathrm{CD} 8^{+} \mathrm{T}$ cells that are specific for the inflationary epitopes exhibit an increased effector-type appearance even after the acute phase of infection (Figure 2B; Figure $\mathrm{S} 1 \mathrm{~B}$ in Supplementary Material). The percentage of inflationary MCMV-specific CM CD8 ${ }^{+} \mathrm{T}$ cells is low throughout infection (Figure S1C in Supplementary Material). Thus, the initial infectious dose has a dominant influence and shapes both the magnitude and phenotype of inflationary MCMV-specific $\mathrm{CD}^{+} \mathrm{T}$ cells.

\section{Analogous Correlations between the Magnitude and Phenotype of Inflationary Mouse and Human CMV-Specific CD8 ${ }^{+}$ T Cells}

Subsequently, we evaluated whether correlations exist between the magnitude and phenotype of the CMV-specific $\mathrm{CD}^{+}$ 

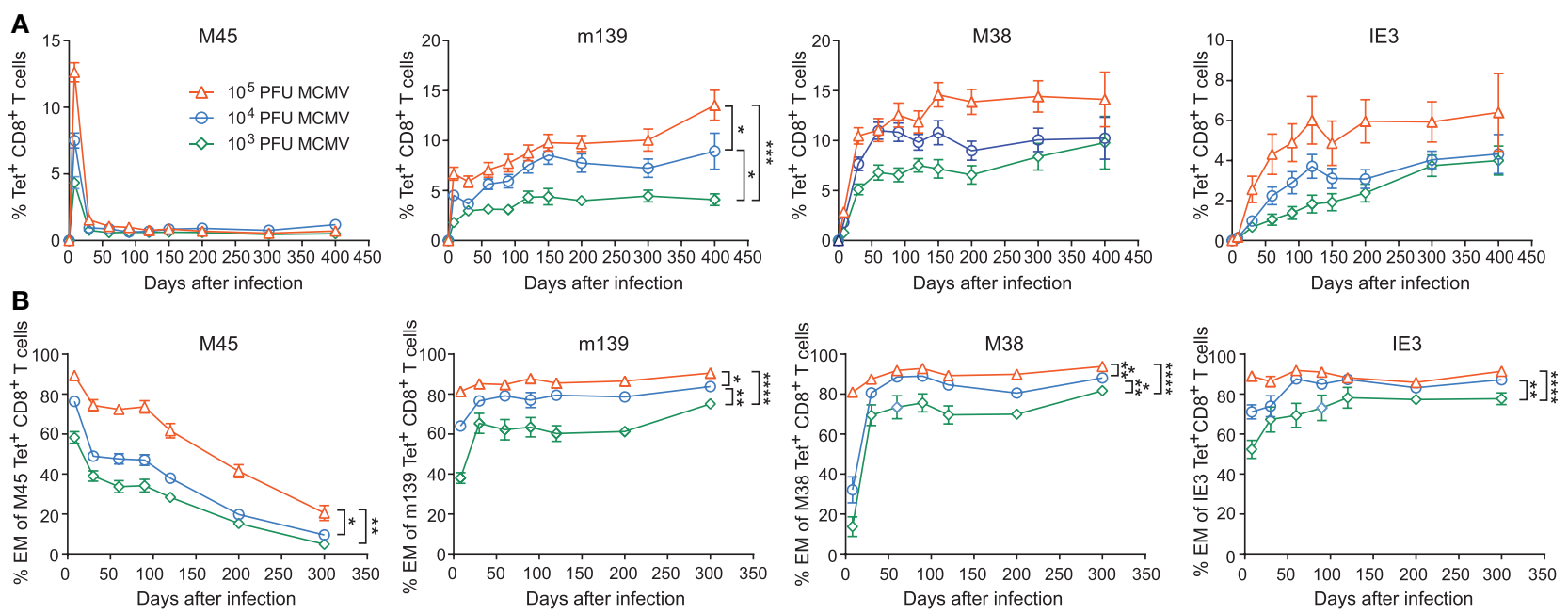

FIGURE 2 | The magnitude and phenotype of inflationary mouse CMV (MCMV)-specific CD8+ T cells is strongly influenced by the inoculum dose. Wild-type (WT) mice were infected with $10^{3}, 10^{4}$, or $10^{5}$ PFU MCMV-Smith. (A) The average frequencies of MCMV-specific CD8 ${ }^{+} \mathrm{T}$ cells (i.e., specific to epitopes derived from the MCMV proteins M45, m139, M38, and IE3) in blood were determined by MHC class I tetramer staining at the indicated time points post-infection. Error bars indicate SEM ( $n=16$ mice per group). (B) Kinetic analysis of the average frequencies of EM (CD44 high CD62L-KLRG1 $\left.{ }^{+}\right)$type CD8+ ${ }^{+}$cells within the total MCMVspecific CD8 ${ }^{+} \mathrm{T}$ cell population in blood. Error bars indicate SEM $\left(n=16\right.$ mice per group). Significance is indicated for day 300 post-infection. ${ }^{\star} P<0.05$; $\left.{ }^{\star \star} P<0.01 ;{ }^{\star \star \star} P<0.001 ;{ }^{\star \star \star \star} P<0.0001\right)$. Data were pooled from two independent experiments.

T cells. Strikingly, only in case of responses against inflationary epitopes, a direct correlation between the magnitude of the MCMV-specific $\mathrm{CD}^{+} \mathrm{T}$ cell response and the frequency of the EM-like cells within the MCMV-specific $\mathrm{CD}^{+} \mathrm{T}$ cell population is observed (Figure 3 ). In mice infected with the lowest dose (i.e., $1 \times 10^{3} \mathrm{PFU}$ ), the magnitude of the $\mathrm{CD}^{+}$ $\mathrm{T}$ cell response against the inflationary epitopes and the frequency of effector cells is correspondingly the lowest, whereas these are highest in infection with the highest dose (i.e., $1 \times 10^{5}$ PFU) (Figure 3A). Also, when we inoculated mice weekly with the same dose of MCMV for a period of 1 year, we found these correlations between the magnitude and phenotype of the inflationary $\mathrm{CD}^{+} \mathrm{T}$ cells, and these correlations were similar to those found in mice infected with MCMV once (Figure 3B). Responses against IE1 in the context of MCMV infection results in a similar correlation as observed for IE3 (data not shown) while IE1 expressed by recombinant vaccinia virus (VACV-IE1), eliciting acute but not persistent infection, did not elicit EM phenotype versus magnitude correlations (Figure 3C), Moreover, the IE1-specific $\mathrm{CD}^{+} \mathrm{T}$ cell response elicited by VACV-IE1 is with respect to the magnitude and EM kinetics similar to the M45-specific response elicited by high-dose MCMV [(23) and data not shown]. Together, these results indicate that viral antigen reactivation is essential for the observed correlations between the magnitude and EM phenotype of the $\mathrm{CD} 8^{+} \mathrm{T}$ cells.

Since humans are likely infected with varying doses of HCMV, we aimed to recapitulate whether the above-described correlations also exist in HCMV-positive individuals. Therefore, we performed analysis of the human pp65-specific $\mathrm{CD}^{+} \mathrm{T}$ cell response in a large cohort of healthy HCMV-seropositive individuals. Essentially, reminiscent to the correlations of the inflationary responses observed in the mouse (Figure 3A), a relationship was observed between the magnitude of the HCMVspecific $\mathrm{CD}^{+} \mathrm{T}$ cell response and the frequency of specific $\mathrm{CD}^{+}$ $\mathrm{T}$ cells harboring an EM phenotype (Figure 3D). Remarkably, the development of the EM phenotype of $\mathrm{CD}^{+} \mathrm{T}$ cells against HCMV pp65 follows analogous kinetics upon primary infection of HCMV-seronegative patients receiving a HCMV-positive kidney transplant as compared to the EM phenotype of the inflationary MCMV epitopes (Figures 2B and 3E). Together, these data indicate that $\mathrm{CD}^{+} \mathrm{T}$ cell responses against viral epitopes in HCMV and MCMV follow a similar developmental pathway in which the EM phenotype of the responding $\mathrm{CD}^{+}$ $\mathrm{T}$ cells correlate with the magnitude of the viral-specific $\mathrm{CD} 8^{+}$ $\mathrm{T}$ cell response.

\section{Progressive EM CD8 ${ }^{+} \mathrm{T}$ Cell Differentiation Is Accelerated by High-Dose CMV Infection}

To gain a more detailed understanding of the phenotypic differences of the MCMV-specific $\mathrm{CD}^{+} \mathrm{T}$ cells that develop during the low, intermediate, and high-dose infection, we used a novel analysis platform, termed Cytosplore (34), for immune cell phenotyping that incorporates approximated $\mathrm{t}$-distributed stochastic neighborhood embedding (A-tSNE) for dimensionality reduction and-the mean-shift clustering algorithm for subset definition, based on the dimensionality reduced data (37). The A-tSNE algorithm lays out cells in a two-dimensional scatter plot, based on similarity of defined markers. Similar cells will be placed closed together in the plot, while slight variations in the level of marker expression will result in gradual positional transitions. The results of the 


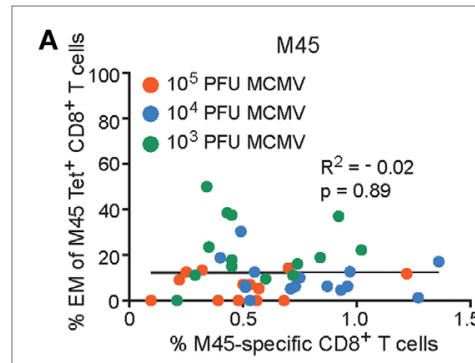

B
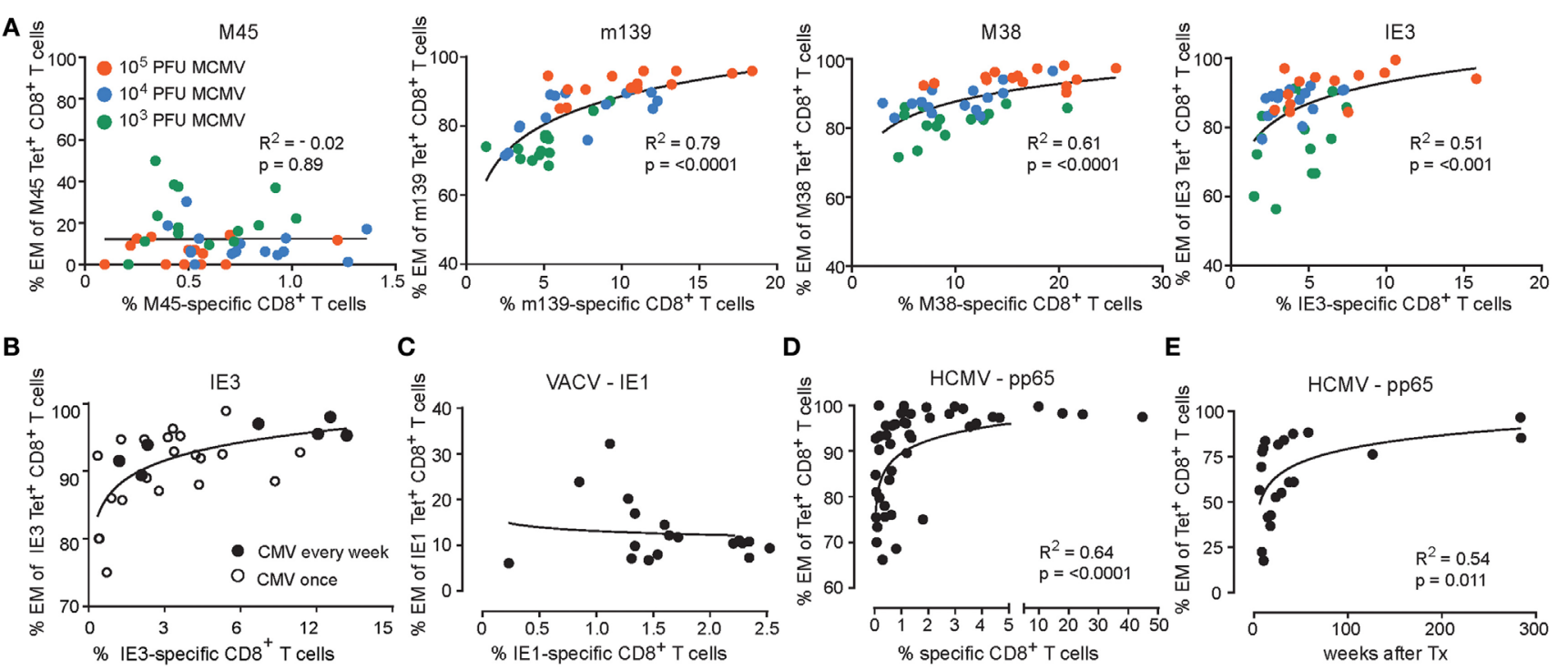

FIGURE 3 | Correlations between the magnitude and phenotype of inflationary CMV-specific T cells. (A) Wild-type (WT) mice were infected with $10^{3}$, $10^{4}$ or $10^{5}$ PFU mouse CMV (MCMV)-Smith. The percentage of MCMV-specific EM (CD44 high CD62L-KLRG1+) CD8+ T cells versus the percentage of MCMV-specific CD8+ ${ }^{+}$cells in blood at day 300 post-infection. Data were pooled from two independent experiments. (B) WT mice were infected with $5 \times 10^{4} \mathrm{PFU}$ MCMV-Smith once $(n=20)$ or weekly $(n=7)$ for 1 year. At 1 year post-infection, the average frequencies and phenotype of IE3-specific CD8 ${ }^{+} \mathrm{T}$ cells in blood was determined by MHC class I tetramer staining. The graph shows the percentage of IE3-specific EM (CD44 high CD62L-KLRG1+) CD8 ${ }^{+} \mathrm{T}$ cells versus the percentage of IE3-specific CD8 ${ }^{+} \mathrm{T}$ cells in blood. (C) WT mice were infected with recombinant vaccinia virus expressing IE1 (VACV-IE1). At day 200 post-infection, the average frequencies and phenotype of

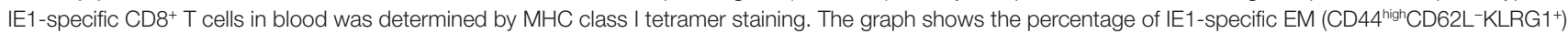
$\mathrm{CD}^{+} \mathrm{T}$ cells versus the percentage of IE1-specific CD8 ${ }^{+} \mathrm{T}$ cells in blood $(n=18)$. (D) Analysis of human cytomegalovirus (HCMV)-specific CD8+ T cell responses. The percentage of antigen-specific EM CD8 ${ }^{+} \mathrm{T}$ cells versus the percentage of antigen-specific CD8 ${ }^{+} \mathrm{T}$ cells in blood from healthy donors for $\mathrm{HCMV}$ pp65 $(n=46)$. (E) The percentage of antigen-specific EM CD8 ${ }^{+} \mathrm{T}$ in blood from initially HCMV-seronegative recipients receiving a HCMV-positive kidney transplant against the weeks after transplantation.

A-tSNE algorithm are then visualized as density plots. This provides an unprecedented insight into the development of the cellular differentiation, which is not feasible by conventional flow cytometry data analysis. We performed Cytosplore analysis on the MCMV-specific $\mathrm{CD}^{+}{ }^{+} \mathrm{T}$ cell populations we tracked in time by MHC class I tetramer staining combined with phenotypical markers comprising CD62L, KLRG1, CD27, and CD44, which allow discrimination between CM- and EM-type $\mathrm{T}$ cells (Figure S2A in Supplementary Material). Such analysis should display the potential differentiation trajectory path of EM- and CM-type T cells. In order to provide an initial global picture of the impact of CMV infection on the EM/CM T cell differentiation, we analyzed each MCMV-specific CD8 ${ }^{+} \mathrm{T}$ cell population in time using the combined data from the different infection dosages. We observed that the development of the EM phenotype of the inflationary T cells is progressive in time, as evidenced by an ongoing shift toward a higher advanced EM phenotype (indicated with red arrows) (Figure 4A). Even between days 120 and 200, the EM differentiation continues. To assess the role of dosing in this phenomenon, we performed the analysis with the separate dosages. Compared to low-dose infection, higher dose infections accelerated the EM CD8 ${ }^{+}$ $\mathrm{T}$ cell differentiation throughout the infection (Figure $\mathbf{4 B}$, shown for IE3; Figure S2B in Supplementary Material, shown for M38). We also observed that the impact of the dosage effect on the EM CD8 ${ }^{+} \mathrm{T}$ cell differentiation is irrespective of the infection duration (Figure S3 in Supplementary Material). Together these data suggest that high-dose infection causes an EM CD8 ${ }^{+} \mathrm{T}$ cell differentiation that not only develops faster but also continues to segregate throughout the life span of the host, suggesting a virus-host equilibrium that is influenced by aging and the infectious dose.

\section{The Dichotomy in Cytokine Polyfunctionality of Inflationary versus Non-Inflationary CMV-Specific T cells Increases with the Infectious Dose}

In elderly individuals, a higher frequency of cytokine-deficient $\mathrm{CD}^{+} \mathrm{T}$ cells recognizing the HCMV epitope pp65 is associated with all-cause mortality in these individuals, suggesting that the presence of these cells could predict age-related dysfunction and increased risk of death (38). To gain insight into the cytokine profile of the MCMV-specific T cells in differentially inoculated aged mice, we assessed the polyfunctional cytokine profiles 400 days after MCMV infection. The majority of the M45-specific $\mathrm{CD}^{+} \mathrm{T}$ cell pool in the spleen comprises the capacity to coproduce IFN- $\gamma$, TNF, and IL-2 (Figure 5A). The frequency of these triple cytokine producers is elevated in mice infected with higher inoculums of MCMV. By contrast, CD8 ${ }^{+}$ $\mathrm{T}$ cell populations specific for the inflationary epitopes (m139, M38, and IE3), consist most frequently of double-producing 


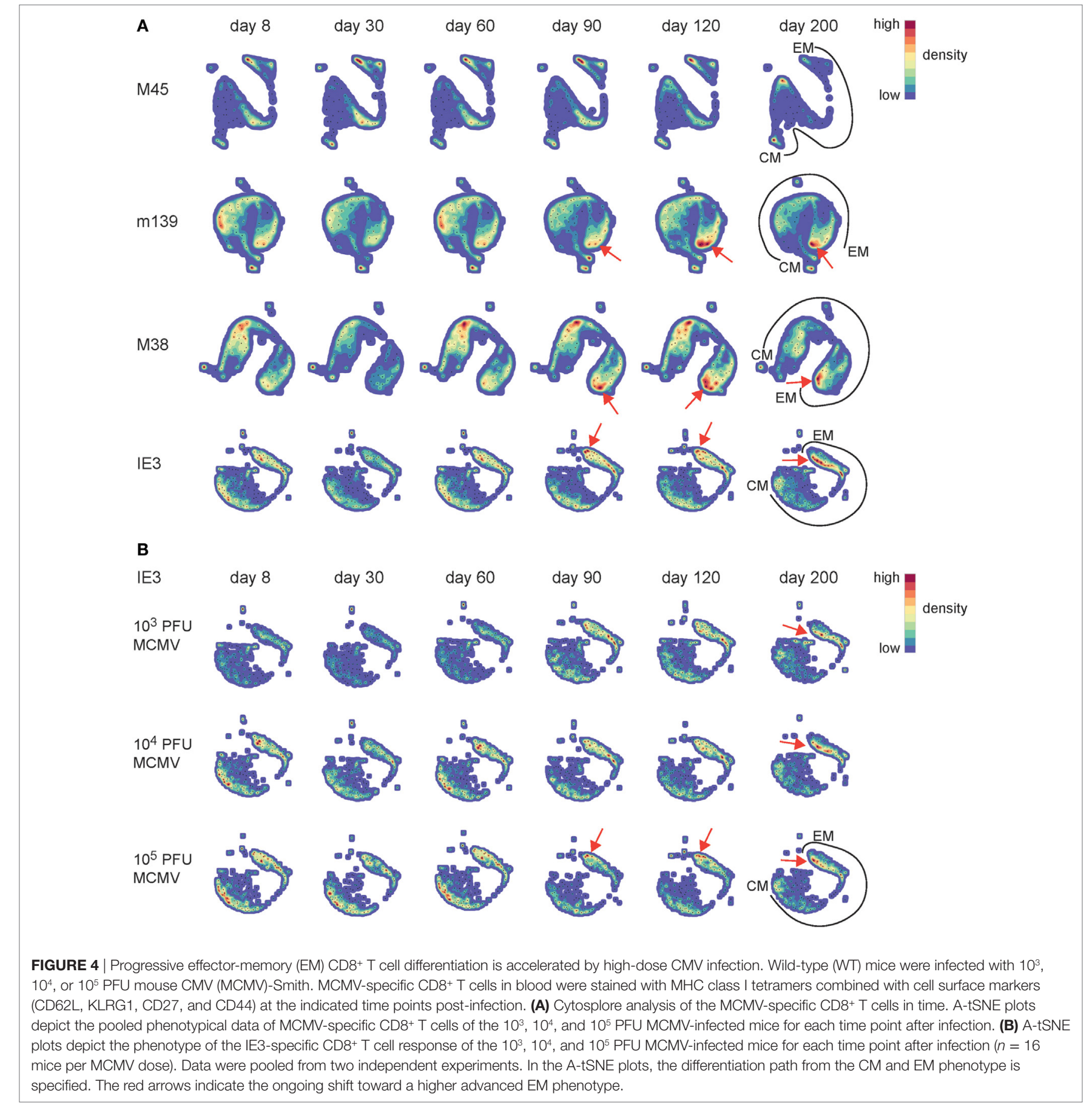

cells (IFN- $\gamma$ and TNF). These frequencies increase with higher MCMV inoculum dosages, while this coincides with decreasing frequencies of triple cytokine producing cells (Figure 5A). Correspondingly, high-dose infection results in elevated absolute numbers of double IFN- $\gamma /$ TNF producers, especially among the inflationary $\mathrm{CD}^{+} \mathrm{T}$ cells (Figure 5B). In the MCMV-specific CD4 ${ }^{+} \mathrm{T}$ cell pool a dose-dependent increase of double cytokine producers is also observed, although mainly at the expense of the single IFN- $\gamma$-producing cells (Figure S4A in Supplementary Material). Thus, whereas non-inflationary
$\mathrm{CD}^{+} \mathrm{T}$ cells have an increment of the most polyfunctional $\mathrm{T}$ cells with higher inoculums, inflationary $\mathrm{CD}^{+} \mathrm{T}$ cells tend to lose this property.

\section{Only High-Dose CMV Infection Impairs the Development of Heterologous T Cell Responses}

To assess whether the initial infectious dosages that determine the degree of the CMV-induced perturbations of peripheral 


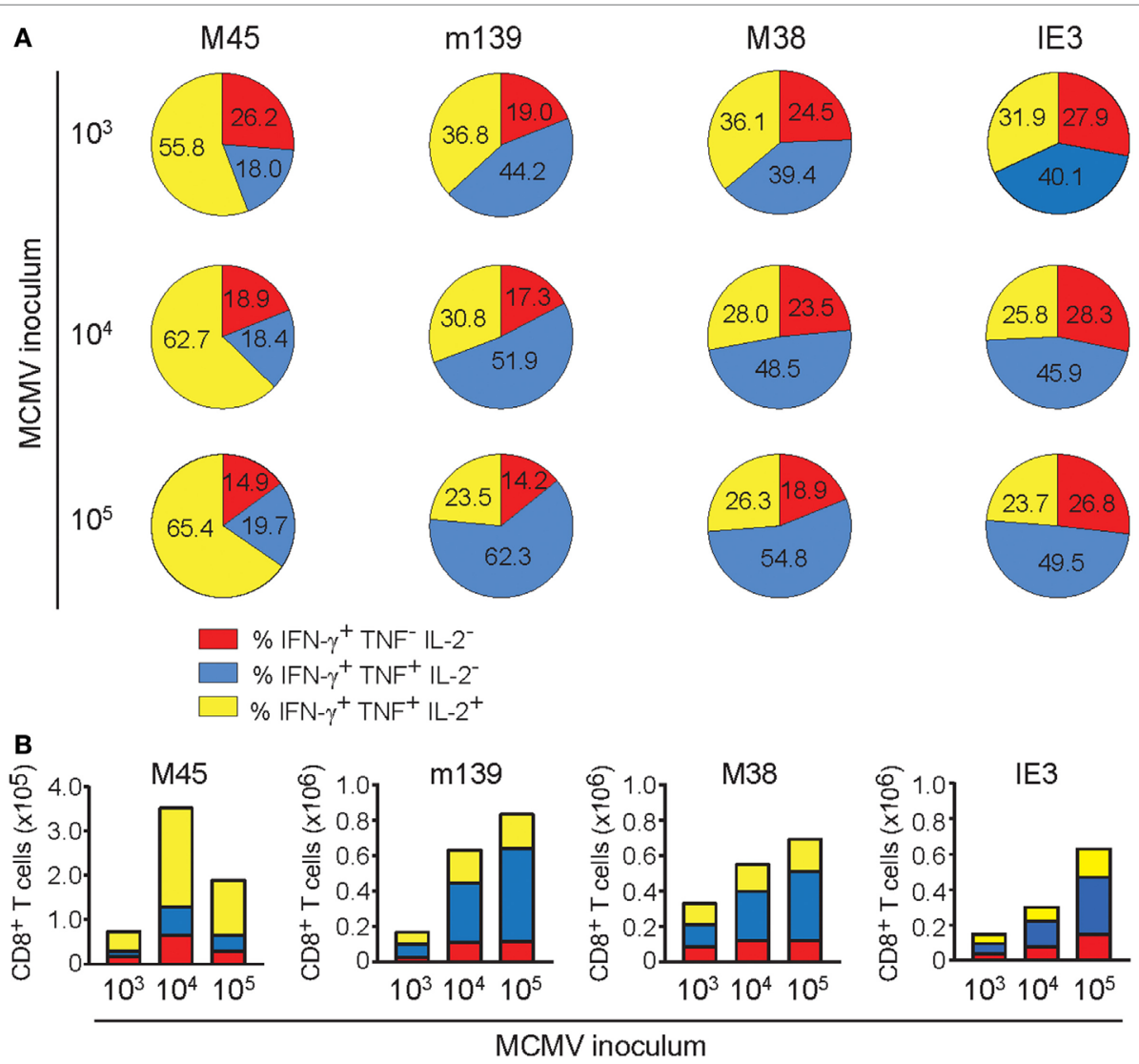

FIGURE 5 | The dichotomy in cytokine polyfunctionality of inflationary versus non-inflationary CMV-specific T cells increases with the infectious dose. Following mouse CMV (MCMV) infection with different dosages $\left(10^{3}, 10^{4}\right.$, or $10^{5} \mathrm{PFU}$ MCMV-Smith), the cytokine polyfunctionality of splenic CD8 $8^{+} \mathrm{T}$ cells was determined after peptide restimulation at day 400 post-infection. (A) Pie charts depict the percentages of the single (IFN- $\gamma$ ), double (IFN- $\gamma / T N F)$, and triple (IFN- $\gamma / T N F / I L-2)$ cytokine producers of each antigen-specific T cell population upon peptide stimulation. (B) Absolute counts of the single (IFN- $\gamma$ ), double (IFN- $\gamma / T N F)$, and triple (IFN- $\gamma / T N F /$ IL-2) cytokine producers of each antigen-specific T cell population upon peptide stimulation. Data represents mean values $(n=8$ per group). Data were pooled from two independent experiments.

naive and memory $\mathrm{T}$ cell compartments is connected to differential impairment of the development of heterologous anti-viral immunity, we challenged 400-day-old naive and MCMVinfected mice $\left(1 \times 10^{3}, 1 \times 10^{4}\right.$, or $1 \times 10^{5}$ PFU MCMV) with $2 \times 10^{5}$ PFU LCMV-Armstrong. LCMV infection significantly increased the absolute splenic $\mathrm{CD} 8^{+} \mathrm{T}$ cell numbers of the naïve mice and of the mice infected with $1 \times 10^{3}$ or $1 \times 10^{4} \mathrm{PFU}$ MCMV compared to age-matched mice that did not receive a LCMV challenge (Figure 6A). Strikingly, in mice that were long-term infected with the highest dose of MCMV $\left(1 \times 10^{5}\right.$ PFU), the LCMV-induced CD ${ }^{+} \mathrm{T}$ cell expansion was impaired and numbers were not significantly increased (Figure 6A). Determination of the effector $\mathrm{CD}^{+} \mathrm{T}$ cell quantities revealed a similar trend; albeit LCMV challenge caused a significant increase in all groups, the expansion was least pronounced when mice were previously infected with the highest dose of MCMV (Figure 6B), suggesting a reduction in LCMV-specific CD8 ${ }^{+}$ $\mathrm{T}$ cells when mice experienced high-dose MCMV inoculums previously. To test this assumption, we determined absolute numbers of LCMV-specific (GP33 $3_{33-41}, \mathrm{NP}_{396-404}$, and $\mathrm{GP}_{276-286}$ )
$\mathrm{CD}^{+} \mathrm{T}$ cells by MHC class I tetramer binding (Figure 6C), and found indeed that the response against these immunodominant LCMV epitopes was mostly reduced in mice that were inoculated with the highest dose of MCMV $\left(1 \times 10^{5} \mathrm{PFU}\right)$. Analysis of the LCMV-specific CD4 ${ }^{+} \mathrm{T}$ cell response $\left(\mathrm{GP}_{61-80}\right)$ as measured by IFN- $\gamma$ production revealed no MCMV-induced perturbations (Figures S4B,C in Supplementary Material). Together, these data suggest that high-dose MCMV infection affects the capacity of immunodominant $\mathrm{CD}^{+} \mathrm{T}$ cells to expand upon heterologous infections.

To assess whether the increasing doses of MCMV could differentially affect the activation status of the LCMV-primed CD8 ${ }^{+}$ T cells, the cell surface expression of CD27, CD127, CD62L, and KLRG1 was evaluated. Strikingly, we found that the frequency of the immunodominant LCMV-specific CD8 ${ }^{+} \mathrm{T}$ cells expressing CD27, and correspondingly the expression of CD27 on a per cell basis, was mostly reduced in mice persistently infected with the highest MCMV dose (Figures 6D,E), while expression of CD127, CD62L, and KLRG1 was not influenced by MCMV infection (Figures S5A-C in Supplementary Material). Next, 

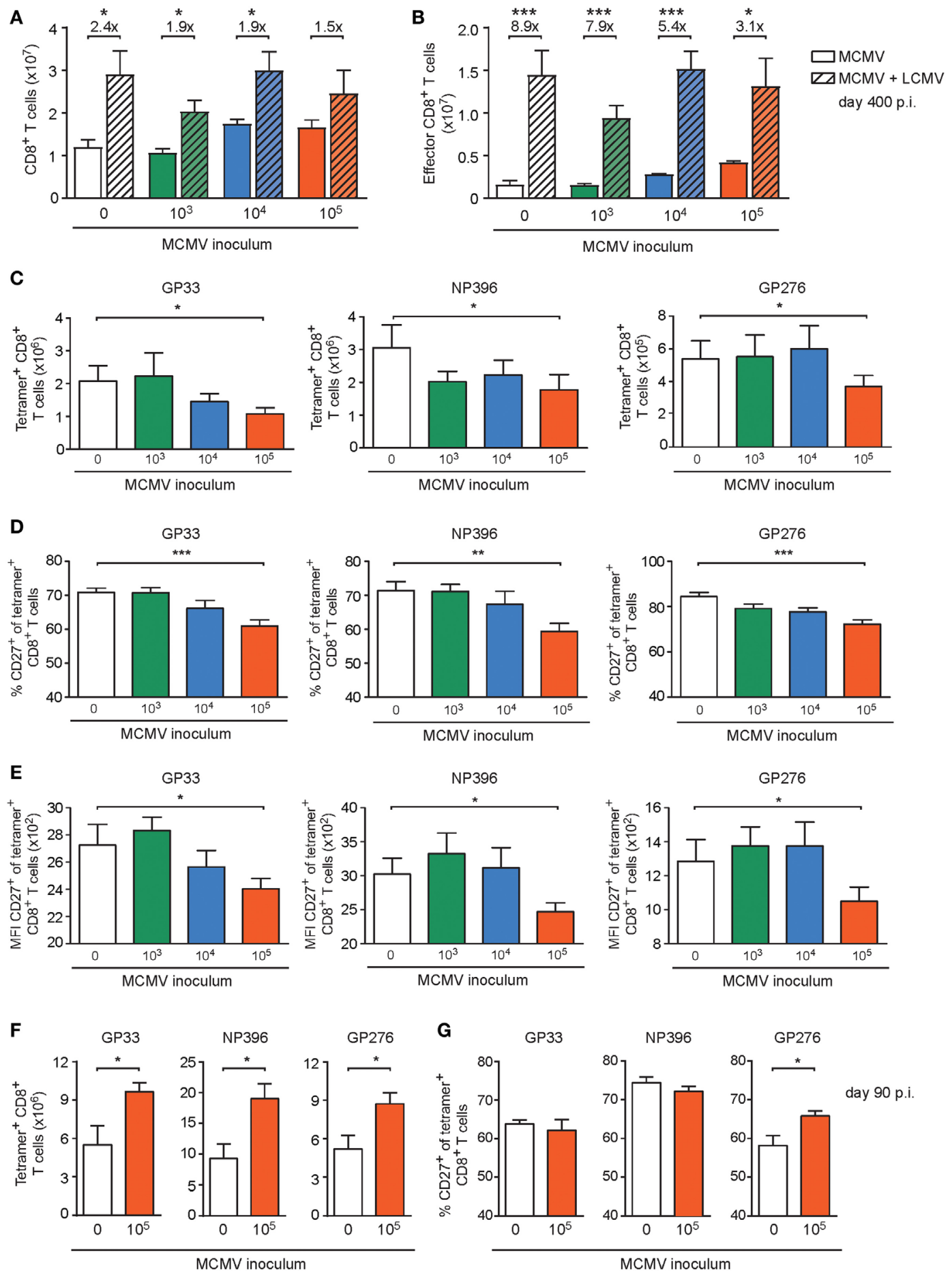

FIGURE 6 | High-dose CMV infection impairs the development of heterologous viral-specific T cell responses. (A-E) Wild-type (WT) mice were kept uninfected or infected with $10^{3}, 10^{4}$, or $10^{5}$ PFU mouse CMV (MCMV)-Smith ( $n=16$ mice per group), and at day 400 post-infection 8 mice per group were challenged with $2 \times 10^{5}$ PFU lymphocytic choriomeningitis virus (LCMV)-Armstrong. At day 8 post LCMV infection, mice were analyzed and compared with uninfected littermate controls. (A) Numbers of total splenic CD8 ${ }^{+}$T cells. (B) Numbers of total effector (CD44 high CD62L- KLRG1+) CD8 ${ }^{+}$T cells. (C) Numbers of splenic LCMV-specific $\mathrm{CD}^{+} \mathrm{T}$ cells determined by MHC class I tetramer staining. (D) Percentage of LCMV-specific CD8+ T cells expressing CD27. (E) Mean fluorescence intensity (MFI) of CD27 expression on LCMV-specific CD8 ${ }^{+} \mathrm{T}$ cells. (F,G) WT mice were kept uninfected or infected with or $10^{5} \mathrm{PFU} \mathrm{MCMV-Smith}(n=8 \mathrm{mice}$ per group), and at day 90 post-infection challenged with $2 \times 10^{5}$ PFU LCMV-Armstrong. At day 8 post LCMV infection, mice were analyzed and compared with uninfected littermate controls. (F) Numbers of splenic LCMV-specific CD8 ${ }^{+} \mathrm{T}$ cells determined by MHC class I tetramer staining. (G) Percentage of LCMV-specific CD8 ${ }^{+} \mathrm{T}$ cells expressing CD27. Results are represented as means and error bars indicate SEM ( $n=8$ mice per group). ${ }^{\star} P<0.05$; ${ }^{\star \star} P<0.01 ;{ }^{\star \star \star} P<0.001$. Data were pooled from two independent experiments. 
we investigated if the impairment of heterologous immune responses due to high-dose CMV infection is related to longterm infection of aged mice. Strikingly, the LCMV-specific $\mathrm{CD}^{+} \mathrm{T}$ cell response in young mice ( 5 months old) that were previously uninfected or infected with a high-dose MCMV $\left(1 \times 10^{5}\right.$ PFU MCMV-Smith) revealed no reduction or even an increase in the amount or activation status of LCMV-specific $\mathrm{CD}^{+} \mathrm{T}$ cells (Figures 6F,G; Figure S5D-G in Supplementary Material).

Next, we aimed to determine if the MCMV dose-associated alterations could also impact the cytokine polyfunctionality of the LCMV-specific CD8 ${ }^{+} \mathrm{T}$ cell responses in the aged MCMVinfected mice after heterologous infection with LCMV. Following ex vivo stimulation with class I-restricted peptides $\mathrm{GP}_{33-41}, \mathrm{NP}_{396-}$ ${ }_{404}$, and $\mathrm{GP}_{276-286}$, the frequencies of the single (IFN- $\gamma$ ), double (IFN- $\gamma$ and TNF), and triple (IFN- $\gamma$, TNF, and IL-2) producing LCMV-specific CD8 ${ }^{+} \mathrm{T}$ cells were determined. Although an obvious altered cytokine profile was not detected (Figure 7A), the responding LCMV-specific T cells exhibited a lower IL-2 expression on a per cell basis in only those mice that were previously inoculated with the highest dose of MCMV (Figure 7B). Analysis of the $\mathrm{CD}^{+} \mathrm{T}$ cell response against the LCMV epitope $\mathrm{GP}_{61-80}$ showed that the cytokine polyfunctionality of the LCMV-specific $\mathrm{CD}^{+} \mathrm{T}$ cells are not affected by lifelong MCMV infection (Figure S4B in Supplementary Material).

Taken together, these results establish that persistent MCMV infection induced by a high inoculum dose is able to decrease the development of heterologous adaptive immune responses upon encountering a new pathogen.

\section{The Inflammatory Milieu and Antibody Levels upon Heterologous Infection Are Influenced by the Inoculum Dose of MCMV}

Chronic low grade inflammation accompanied with persistent CMV infection might affect antigen-presenting cells in such a way that the priming of $\mathrm{T}$ cells against newly encountered antigens is hampered. To test whether the size of the inoculum dose might influence low grade inflammation in steady state
A

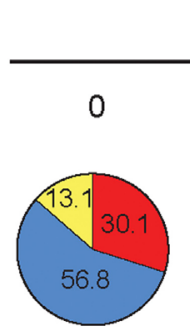

4.75

NP396
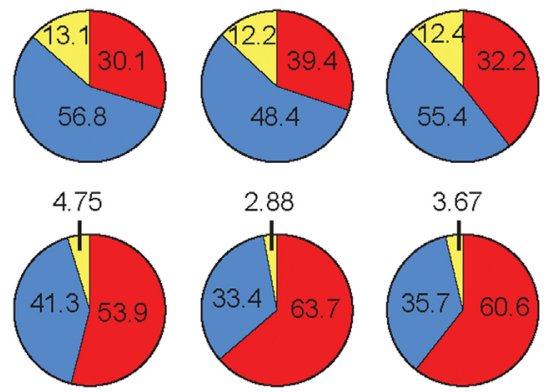

3.67
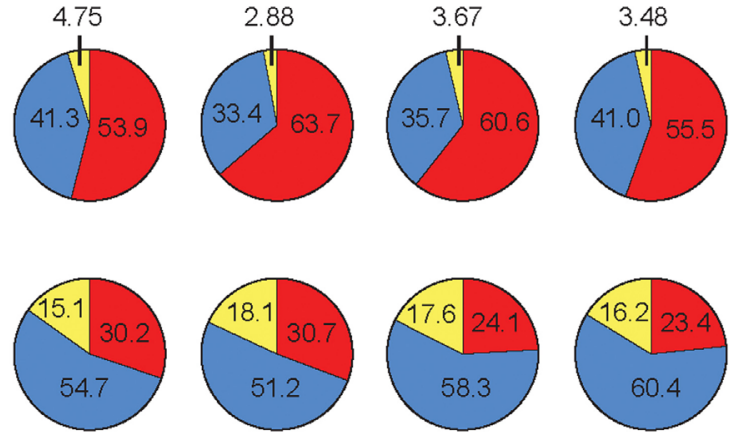

B
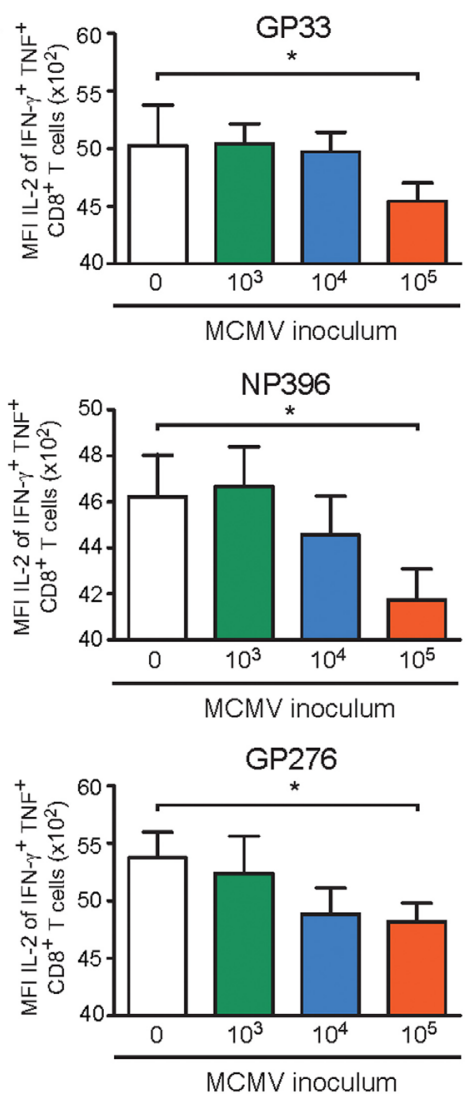

FIGURE 7 | High-dose CMV infection impairs the autocrine IL-2 production of heterologous viral-specific T cells. Wild-type (WT) mice were kept uninfected or infected with $10^{3}, 10^{4}$, or $10^{5} \mathrm{PFU}$ mouse CMV (MCMV)-Smith, and at day 400 post-infection 8 mice per group were challenged with $2 \times 10^{5}$ PFU lymphocytic choriomeningitis virus (LCMV)-Armstrong. At day 8 post LCMV infection, mice were analyzed and compared with uninfected littermate controls. (A) The cytokine polyfunctionality of splenic CD8 ${ }^{+} \mathrm{T}$ cells was determined after peptide restimulation. Pie charts depict the percentages of the single (IFN- $\gamma$ ), double (IFN- $\gamma / \mathrm{TNF}$ ), and triple (IFN- $\gamma / T N F / I L-2)$ cytokine producers of each antigen-specific T cell population upon peptide stimulation. (B) MFI of IL-2 expression of LCMV-specific CD8+ T cells. All data represents mean values $+\operatorname{SEM}\left(n=8\right.$ per group, $\left.{ }^{\star} P<0.05\right)$. Data were pooled from two independent experiments. 
and upon heterologous infection, we determined cytokine and chemokine serum levels. Analysis of the tested cytokine and chemokine levels revealed no substantial changes between mice that were infected with different doses of MCMV at day 400 post MCMV infection (Figure S6 in Supplementary Material). Upon LCMV infection, we observed for a number of cytokines/chemokines a major increase, albeit mostly this was not influenced by the MCMV inoculum dose. However, a MCMV dose-dependent decrease in IFN- $\gamma$ serum levels is apparent (Figure 8A). For the TNF serum levels the same trend was observed (Figure 8B). Analysis of the IL-2 serum concentration revealed that IL-2 levels were lower in the high MCMV dose inoculating mice (Figure $\mathbf{8 C}$ ), which corresponds to the lower amounts of IL-2 produced by the inflationary T cells. In contrast to the other cytokines present in serum, upon LCMV infection the IL-2 levels decreased in the mice without prior MCMV infection and in the mice inoculated with $1 \times 10^{3}$ and $1 \times 10^{4} \mathrm{PFU}$. Whereas in mice that experienced lifelong infection with the highest MCMV dose, the IL-2 concentration increased, suggesting a lower rate of IL-2 consumption by the $\mathrm{T}$ cells (Figure $\mathbf{8 C}$ ). Thus, the MCMV inoculum dose differentially shapes the inflammatory milieu with respect to effector T cell-associated cytokines (IFN- $\gamma$, TNF, IL-2) upon encountering a new pathogen.
Given the correlation between MCMV-specific antibody titers and the infectious dose (Figure 8D), we aimed to address whether the MCMV inoculum dosage particularly affects heterologous $\mathrm{T}$ cell responses or whether also heterologous B cell responses are influenced. In the MCMV-infected mice 8 days after LCMV infection the LCMV-specific IgM antibody induction was hampered and only in those mice that were previously inoculated with high-dose MCMV (Figure 8E). In young mice with and without a latent MCMV infection that were challenged with LCMV a reverse trend was observed. In these mice the LCMV-specific IgM production was increased in mice with a latent MCMV infection (Figure 8F). Thus, only in aged mice the MCMV inoculum size inversely correlates with LCMV-specific IgM induction after heterologous infection.

\section{High-Dose CMV Infection Hampers Control of Heterologous Infections and Correlates to the Phenotypical Alterations of Virus-Specific CD8 ${ }^{+}$T Cells}

To determine if the aforementioned MCMV-induced immune alterations resulted in hampered LCMV control, we determined the LCMV viral load in the lungs and kidneys of the uninfected and MCMV-infected mice. We observed that compared to
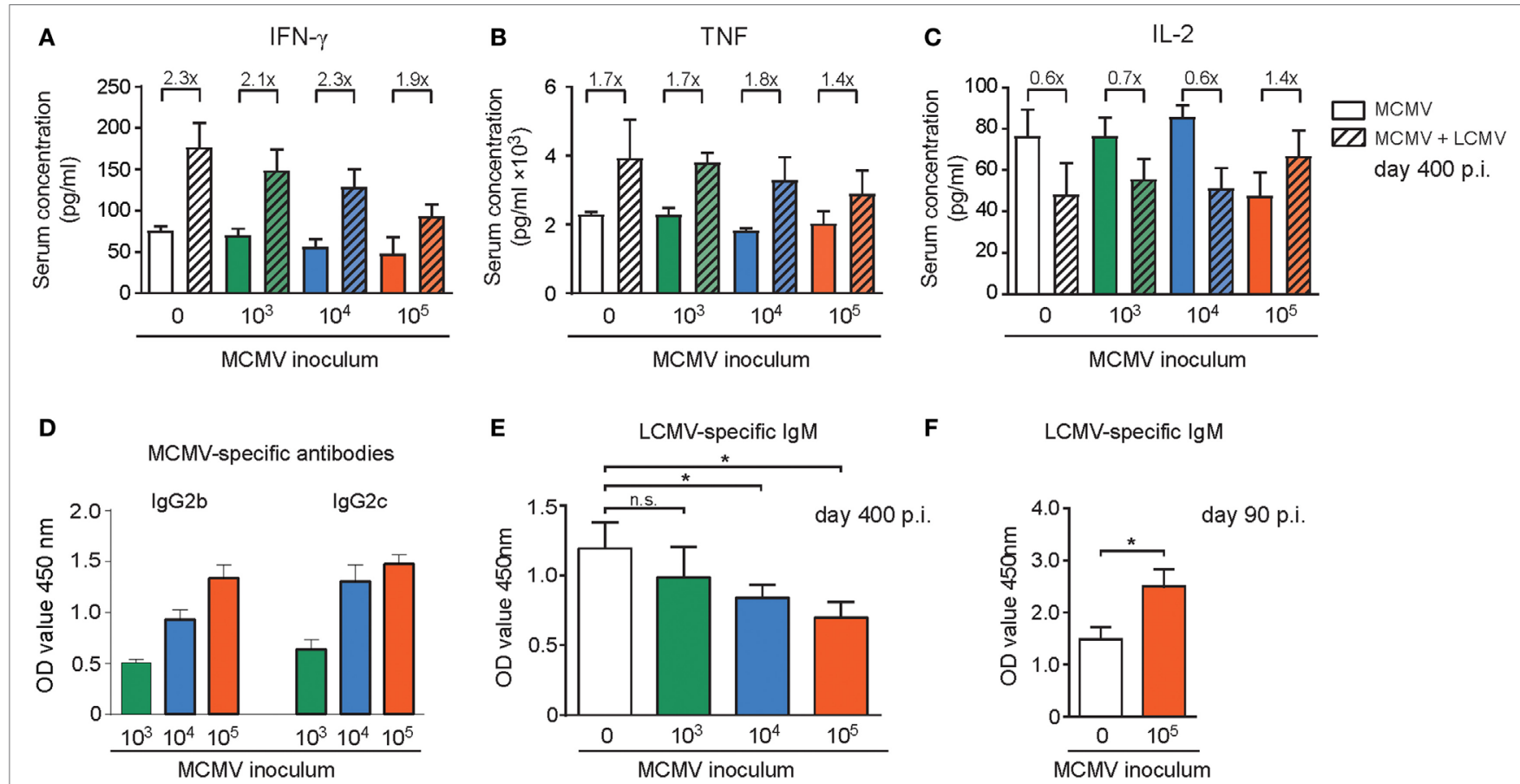

FIGURE 8 | The inflammatory milieu and antibody levels upon heterologous infection are shaped by the inoculum dose of mouse CMV (MCMV). (A-E) Wild-type (WT) mice were kept uninfected or infected with $10^{3}, 10^{4}$, or $10^{5}$ PFU MCMV-Smith ( $n=16$ mice per group), and at day 400 post-infection 8 mice per group were challenged with $2 \times 10^{5}$ PFU lymphocytic choriomeningitis virus (LCMV)-Armstrong. At day 8 post LCMV infection, mice were analyzed and compared with uninfected littermate controls. Cytokines and chemokines in the serum were determined by mouse cytokine bio-plex immunoassays (A-C), and MCMV (D) or LCMV-specific (E,F) antibody levels were determined by ELISA. (A-C) Shown are the serum concentrations of IFN- $\gamma$ (A), TNF (B), and IL-2 (D). MCMV-specific IgG antibody levels in LCMV unchallenged mice (E) Levels of LCMV-specific IgM antibodies in LCMV-challenged mice. (F) WT mice were kept uninfected or infected with $10^{5}$ PFU MCMV-Smith, and at day 90 post-infection mice were challenged with $2 \times 10^{5}$ PFU LCMV-Armstrong. Blood was taken 8 days after LCMV infection and levels of LCMV-specific IgM antibodies within the serum were determined. Data represents mean values $+\mathrm{SEM}\left(n=8\right.$ per group, $\left.{ }^{\star} P<0.05\right)$. Data were pooled from two independent experiments. 
MCMV-naive mice the viral load was significantly increased in mice that were inoculated with $1 \times 10^{5} \mathrm{PFU}$ MCMV. Importantly, in mice that were inoculated with lower doses of MCMV, control of LCMV replication was not significantly affected (Figure 9A). Importantly in young mice inoculated with a high-dose, LCMV infection was even slightly better controlled (Figure 9B).

The frequency of EM T cells in peripheral blood of aged mice correlates with the inoculum dose while an inverse correlation is seen for $\mathrm{CM} \mathrm{CD}^{+} \mathrm{T}$ cells. To determine whether the frequency of EM CD8 ${ }^{+} \mathrm{T}$ cells before challenge with LCMV also correlates with the ability to control heterologous infection, we plotted the EM frequencies of the total $\mathrm{CD}^{+} \mathrm{T}$ cell population against the LCMV viral load in the lungs. Clearly, a strong connection between the EM phenotype and LCMV titers in the lungs is observed (Figure 9C). A reverse correlation was found when the frequency of CM T cells was plotted (Figure 9D). These data indicate that the frequency of $\mathrm{EM} \mathrm{CD} 8^{+} \mathrm{T}$ cells (or inversely the $\mathrm{CM} \mathrm{CD} 8^{+} \mathrm{T}$ cells) can be used as predictors of a possible defective capacity of the host to respond to newly encountered pathogens.

\section{DISCUSSION}

The possible contribution of CMV to immune senescence has received considerable attention but remained controversial $(20,21)$. To extend our knowledge with respect to the role of $\mathrm{CMV}$ in immune senescence, we performed a highly controlled prospective study revealing that the size of the initial viral inoculum dictates the degree of CMV-induced immune alterations in long-lasting infection. Our data revealed a clear correlation between the magnitude of the $\mathrm{CD}^{+} \mathrm{T}$ cell response and the frequency of CMV-specific CD8 ${ }^{+} \mathrm{T}$ cells exhibiting an EM phenotype, which was apparent in CMV-infected mice and humans. Importantly, we show that solely a high CMV infectious dose results in immune perturbations that are substantial enough to impair heterologous anti-viral immunity, thereby providing a better understanding of CMV in immune senescence and in addition settles previous controversies in this respect.

In agreement with our results, several studies have shown that MCMV infection with a high infectious dose causes immune perturbations that impair $\mathrm{CD}^{+} \mathrm{T}$ cell immunity later in life (22-24).

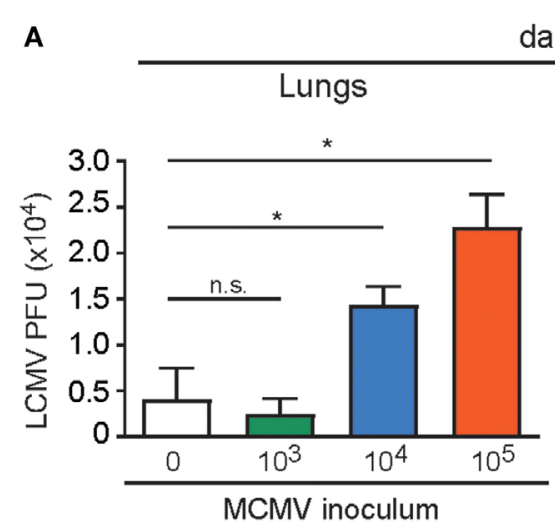

C

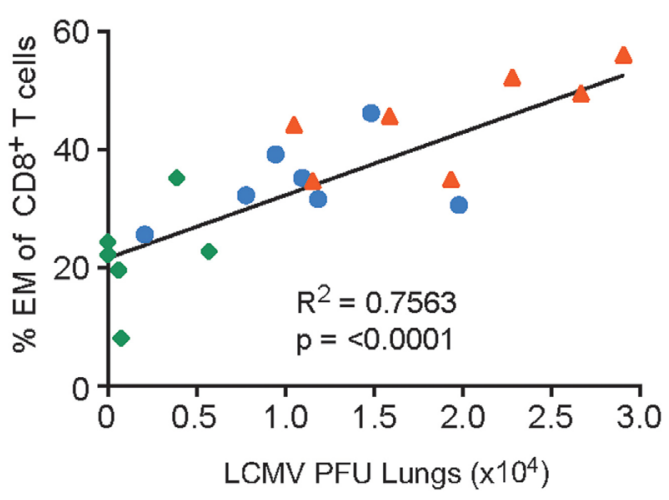

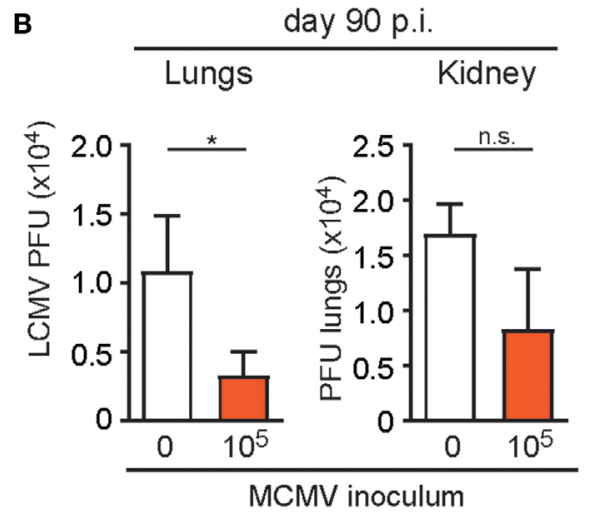

MCMV inoculum

FIGURE 9 | High-dose CMV infection hampers control of heterologous infections and correlates to the phenotypical alterations of virus-specific CD8 ${ }^{+} \mathrm{T}$ cells. (A) Wild-type (WT) mice were kept uninfected or infected with 103, 104, or 105 PFU mouse CMV (MCMV)-Smith ( $n=16$ mice per group), and at day 400 post-infection 8 mice per group were challenged with $2 \times 10^{5}$ PFU lymphocytic choriomeningitis virus (LCMV)-Armstrong. At day 8 post LCMV infection, mice were analyzed for the LCMV viral load in lungs and kidneys. (B) WT mice were kept uninfected or infected with or $10^{5}$ PFU MCMV-Smith ( $n=8$ mice per group), and at day 90 postinfection challenged with $2 \times 10^{5}$ PFU LCMV-Armstrong. At day 8 post LCMV infection, mice were analyzed for the LCMV viral load. (A,B) All data represents mean values + SEM ( $n=8$ per group). n.s. $P>0.05 ;{ }^{*} P<0.05 ;{ }^{*} P<0.01$. (C-D) Correlation between lung LCMV titers and the frequency of peripheral effectormemory (EM) (C) and central-memory (CM) (D) $C D 8^{+} T$ cells 400 days post-infection of the same mice. Pearson's correlations were used to determine the strength of the correlations ${ }^{\star \star \star \star} P<0.0001$. Data were pooled from two independent experiments. 
Previously, we have shown that the influence of CMV on eliciting inflationary EM-like $\mathrm{CD}^{+} \mathrm{T}$ cells populations is depending on the inoculum dose (27). In the current study, we have appreciated this differential impact of dissimilar CMV dosages and show that CMV infection does not by definition impairs immunity, but specifically a high infectious dose is a prerequisite for CMV-associated immune senescence. Conceivably, in immune compromised hosts where viral control is hampered, already a low viral dose might result in CMV-related immune senescence. Although we have shown that weekly reinfection with the same dose does not increase EM T cell accumulation, it should be noted that in addition to the initial infectious dose, the CMV dosage during reinfection and the level of pre-existing CMV-specific neutralizing antibodies could impact the degree of $\mathrm{CD}^{+} \mathrm{T}$ cell accumulation. We assume that in humans, where reinfection is known to occur (39), the viral dose differs in subsequent reinfection. We consider it likely that CMV reinfection with increasing infectious doses does intensify the degree of EM T cell accumulation and, hence, thereby possibly immune senescence.

In human individuals, correlations between HCMV positivity and impaired immunity are controversial since this relationship is observed in some but not all studies (12-18, 40-44). Our results can at least partly explain this controversy, because it is highly conceivable that in humans CMV infection occurs with infectious dosages that are highly variable. In addition, besides the infectious dose also host intrinsic factors such as genetic predisposition can impact the CMV grade, and hence, contribute possibly to immune senescence.

The accumulation of CMV-specific EM CD8 ${ }^{+} \mathrm{T}$ cells, which correlate with impaired heterologous immunity, might by itself be (partly) causative for the negative impact of long-standing latent CMV on heterologous immunity. In case of high-dose infection, the frequency of CMV-specific $\mathrm{CD} 8^{+} \mathrm{T}$ cells might reach a certain threshold resulting in diminished priming of naive $\mathrm{T}$ cells against newly encountered pathogens. Indeed, detailed cluster analysis of the EM development of the circulating CMV-specific CD8 ${ }^{+}$ $\mathrm{T}$ cells showed that high-dose infection causes a differentiation pathway that progresses faster throughout the life span of the host, suggesting a virus-host equilibrium that is not fixed and apparently is influenced by aging and the infectious dose. Whether ongoing EM differentiation takes also place in tissues requires further investigations. A higher infectious dose is known to result in a higher level of reactivation from latency (45) and this is in line with the observation that a higher CMV dose results in larger reservoirs of latent CMV (27). As a result, stimulation of CMVspecific $\mathrm{T}$ cells is increased, thereby accelerating differentiation. Moreover, we observed that the LCMV-specific CD8 ${ }^{+} \mathrm{T}$ cells in mice infected with a high CMV dose are not properly primed as evidenced by decreased upregulation of CD27 and lower IL-2 production. It is considered that in aged individuals priming occurs less as compared to young (46). The additional amounts of (activated) $\mathrm{T}$ cells might further diminish this by competing for $\mathrm{T}$ cell growth factors or even by competition at the APC level. Nonetheless, we consider it likely that the accumulation of CMV-specific $\mathrm{T}$ cells is not solely responsible for impairing immune responses against newly encountered pathogens. For example, our analysis also revealed a weakened LCMV-specific
$\mathrm{B}$ cell response in those mice that were infected with the highest dose of MCMV. In mouse and human CMV infection, accumulation of CMV-specific antibodies has been reported $(27,47,48)$. This may indicate that also accumulation of CMV-specific antibody-producing B cells occurs. Possibly these CMV-specific plasma cells compete with B cells that are specific for the newly encountered pathogen.

In contrast to what we observed in aged mice, in young mice CMV infection seems to improve immunity against other pathogens, which is in agreement with other reports showing beneficial effects of herpesvirus infection on protection from other infections $(18,49)$. However, the positive effects of herpesvirus infections in young mice is transient $(18,49,50)$, which may be due to a temporary effect on both the innate and adaptive immune system. In addition, Furman et al. showed that CMV-seropositive young adults displayed an increase in $\mathrm{CD}^{+} \mathrm{T}$ cell sensitivity and an improvement in the antibody response upon influenza vaccination, and it was shown that IFN- $\gamma$ was required for the CMV-associated improved crossprotection (18). Upon heterologous challenge with LCMV, we observed that serum levels of IFN $-\gamma$ were significantly reduced in mice that were infected with the highest dose of CMV compared to mice that were CMV negative. This suggests that a "fit" immune system in which IFN- $\gamma$ production is properly induced is crucial for the CMV-associated enhancement of heterologous immune responses. We consider it likely that aging by itself abolishes the positive effect of CMV by decreasing the IFN- $\boldsymbol{\gamma}$-producing capacity and that a combination of old age and extensive CMV-induced immune aberrations shift the balance toward a negative effect of CMV on heterologous immunity.

In summary, our results demonstrate that the infectious dose of $\mathrm{CMV}$ is a key determinant for the immunological outcome and consequently, also projects the possible impact for heterologous immunity later in life. Importantly, here we show for the first time that only infection with a high CMV infectious dose impairs the immune response against newly encountered pathogens in aged hosts. Thus, reduction of the latent/lytic viral load (by anti-viral drugs or vaccination) can be beneficial to diminish $\mathrm{CMV}$-associated immune senescence. Future prospective longitudinal studies that incorporate stratification based on the strength of the HCMV-specific immune response are required to further delineate the contribution of CMV to immune senescence.

\section{ETHICS STATEMENT}

The inclusion of patients has been conducted in accordance with the ethical principles set out in the Declaration of Helsinki. Both patient inclusion and blood sample collection were done with approval of the Amsterdam Medical Center Medical Ethical Committee. Written informed consent was obtained prior to data collection.

All animal experiments were approved by the Animal Experiments Committee of the Leiden University Medical Center (LUMC) and performed according to the Dutch Experiments on Animals Act that serves the implementation of "Guidelines on 
the protection of experimental animals" by the Council of Europe and the guide to animal experimentation set by the LUMC.

\section{AUTHOR CONTRIBUTIONS}

AR designed and performed most of the experiments and data analysis, and wrote the manuscript. ER performed and analyzed the flow cytometry experiments of HCMV seropositive individuals, and reviewed the manuscript. EG and SW conducted experiments, assisted with flow cytometry and reviewed the manuscript. TH supported the Cytosplore analysis and reviewed the manuscript. FK supported the Cytosplore analysis and reviewed the manuscript. LC-S and JN-Ž performed some of the experiments and reviewed the manuscript. IB and RL reviewed the manuscript. VU supported the Cytosplore analysis and reviewed the manuscript. RA designed and supervised the study, wrote the manuscript, and provided major funding for the study.

\section{REFERENCES}

1. Nikolich-Zugich J. Aging of the T cell compartment in mice and humans: from no naive expectations to foggy memories. JImmunol (2014) 193(6):2622-9. doi:10.4049/jimmunol.1401174

2. Cannon MJ, Schmid DS, Hyde TB. Review of cytomegalovirus seroprevalence and demographic characteristics associated with infection. Rev Med Virol (2010) 20(4):202-13. doi:10.1002/rmv.655

3. Sylwester AW, Mitchell BL, Edgar JB, Taormina C, Pelte C, Ruchti F, et al. Broadly targeted human cytomegalovirus-specific CD4+ and CD8+ T cells dominate the memory compartments of exposed subjects. J Exp Med (2005) 202(5):673-85. doi:10.1084/jem.20050882

4. Vescovini R, Biasini C, Fagnoni FF, Telera AR, Zanlari L, Pedrazzoni M, et al. Massive load of functional effector CD4+ and CD8+ T cells against cytomegalovirus in very old subjects. J Immunol (2007) 179(6):4283-91. doi:10.4049/jimmunol.179.6.4283

5. Karrer U, Sierro S, Wagner M, Oxenius A, Hengel H, Koszinowski UH, et al. Memory inflation: continuous accumulation of antiviral CD8+ T cells over time. J Immunol (2003) 170(4):2022-9. doi:10.4049/jimmunol.170. 4.2022

6. O'Hara GA, Welten SP, Klenerman P, Arens R. Memory T cell inflation: understanding cause and effect. Trends Immunol (2012) 33(2):84-90. doi:10.1016/j. it.2011.11.005

7. Klenerman P, Oxenius A. T cell responses to cytomegalovirus. Nat Rev Immunol (2016) 16(6):367-77. doi:10.1038/nri.2016.38

8. Simon CO, Holtappels R, Tervo HM, Bohm V, Daubner T, Oehrlein-Karpi SA, et al. CD8 T cells control cytomegalovirus latency by epitope-specific sensing of transcriptional reactivation. J Virol (2006) 80(21):10436-56. doi:10.1128/ JVI.01248-06

9. Dekhtiarenko I, Ratts RB, Blatnik R, Lee LN, Fischer S, Borkner L, et al. Peptide processing is critical for T-cell memory inflation and may be optimized to improve immune protection by CMV-based vaccine vectors. PLoS Pathog (2016) 12(12):e1006072. doi:10.1371/journal.ppat.1006072

10. Olsson J, Wikby A, Johansson B, Lofgren S, Nilsson BO, Ferguson FG. Age-related change in peripheral blood T-lymphocyte subpopulations and cytomegalovirus infection in the very old: the Swedish longitudinal OCTO immune study. Mech Ageing Dev (2000) 121(1-3):187-201. doi:10.1016/ S0047-6374(00)00210-4

11. Wikby A, Johansson B, Olsson J, Lofgren S, Nilsson BO, Ferguson F. Expansions of peripheral blood CD8 T-lymphocyte subpopulations and an association with cytomegalovirus seropositivity in the elderly: the Swedish NONA immune study. Exp Gerontol (2002) 37(2-3):445-53. doi:10.1016/ S0531-5565(01)00212-1

12. Frasca D, Diaz A, Romero M, Landin AM, Blomberg BB. Cytomegalovirus (CMV) seropositivity decreases B cell responses to the influenza vaccine. Vaccine (2015) 33(12):1433-9. doi:10.1016/j.vaccine.2015.01.071

\section{ACKNOWLEDGMENTS}

We would like to thank Guillaume Beyrend, Kees Franken, and Els van Beelen for technical assistance. We are grateful to Mark R. Wills and Sarah E. Jackson for critical reading of the manuscript.

\section{FUNDING}

This work was supported by a Gisela Thier grant from Leiden University Medical Center to RA.

\section{SUPPLEMENTARY MATERIAL}

The Supplementary Material for this article can be found online at http:/www.frontiersin.org/articles/10.3389/fimmu.2017.01953/ full\#supplementary-material.

13. Derhovanessian E, Theeten H, Hahnel K, Van Damme P, Cools N, Pawelec G Cytomegalovirus-associated accumulation of late-differentiated CD4 T-cells correlates with poor humoral response to influenza vaccination. Vaccine (2013) 31(4):685-90. doi:10.1016/j.vaccine.2012.11.041

14. Trzonkowski P, Mysliwska J, Szmit E, Wieckiewicz J, Lukaszuk K, Brydak LB, et al. Association between cytomegalovirus infection, enhanced proinflammatory response and low level of anti-hemagglutinins during the anti-influenza vaccination - an impact of immunosenescence. Vaccine (2003) 21(25-26):3826-36. doi:10.1016/S0264-410X(03)00309-8

15. Alonso Arias R, Moro-Garcia MA, Echeverria A, Solano-Jaurrieta JJ, Suarez-Garcia FM, Lopez-Larrea C. Intensity of the humoral response to cytomegalovirus is associated with the phenotypic and functional status of the immune system. J Virol (2013) 87(8):4486-95. doi:10.1128/JVI.02425-12

16. den Elzen WP, Vossen AC, Cools HJ, Westendorp RG, Kroes AC, Gussekloo J. Cytomegalovirus infection and responsiveness to influenza vaccination in elderly residents of long-term care facilities. Vaccine (2011) 29(29-30):4869-74. doi:10.1016/j.vaccine.2011.03.086

17. Strindhall J, Ernerudh J, Morner A, Waalen K, Lofgren S, Matussek A, et al. Humoral response to influenza vaccination in relation to pre-vaccination antibody titres, vaccination history, cytomegalovirus serostatus and CD4/CD8 ratio. Infect Dis (2016) 48(6):436-42. doi:10.3109/23744235.2015.1135252

18. Furman D, Jojic V, Sharma S, Shen-Orr SS, Angel CJ, Onengut-Gumuscu S, et al. Cytomegalovirus infection enhances the immune response to influenza. Sci Transl Med (2015) 7(281):281ra43. doi:10.1126/scitranslmed.aaa2293

19. Wald A, Selke S, Magaret A, Boeckh M. Impact of human cytomegalovirus (CMV) infection on immune response to pandemic $2009 \mathrm{H} 1 \mathrm{~N} 1$ influenza vaccine in healthy adults. J Med Virol (2013) 85(9):1557-60. doi:10.1002/ jmv.23642

20. Sansoni P, Vescovini R, Fagnoni FF, Akbar A, Arens R, Chiu YL, et al. New advances in CMV and immunosenescence. Exp Gerontol (2014) 55:54-62. doi:10.1016/j.exger.2014.03.020

21. Arens R, Remmerswaal EB, Bosch JA, van Lier RA. 5(th) International Workshop on CMV and Immunosenescence - A shadow of cytomegalovirus infection on immunological memory. Eur J Immunol (2015) 45(4):954-7. doi:10.1002/eji.201570044

22. Smithey MJ, Li G, Venturi V, Davenport MP, Nikolich-Zugich J. Lifelong persistent viral infection alters the naive $\mathrm{T}$ cell pool, impairing CD8 T cell immunity in late life. J Immunol (2012) 189(11):5356-66. doi:10.4049/ jimmunol.1201867

23. Cicin-Sain L, Brien JD, Uhrlaub JL, Drabig A, Marandu TF, Nikolich-Zugich J. Cytomegalovirus infection impairs immune responses and accentuates T-cell pool changes observed in mice with aging. PLoS Pathog (2012) 8(8):e1002849. doi:10.1371/journal.ppat.1002849

24. Mekker A, Tchang VS, Haeberli L, Oxenius A, Trkola A, Karrer U. Immune senescence: relative contributions of age and cytomegalovirus infection. PLoS Pathog (2012) 8(8):e1002850. doi:10.1371/journal.ppat.1002850 
25. Cope AV, Sweny P, Sabin C, Rees L, Griffiths PD, Emery VC. Quantity of cytomegalovirus viruria is a major risk factor for cytomegalovirus disease after renal transplantation. J Med Virol (1997) 52(2):200-5. doi:10.1002/ (SICI)1096-9071(199706)52:2<200::AID-JMV14>3.0.CO;2-O

26. Kouri V, Correa CB, Verdasquera D, Martinez PA, Alvarez A, Aleman Y, et al. Diagnosis and screening for cytomegalovirus infection in pregnant women in Cuba as prognostic markers of congenital infection in newborns: 2007-2008. Pediatr Infect Dis J (2010) 29(12):1105-10. doi:10.1097/ INF.0b013e3181eb7388

27. Redeker A, Welten SP, Arens R. Viral inoculum dose impacts memory T-cell inflation. Eur J Immunol (2014) 44(4):1046-57. doi:10.1002/eji.201343946

28. Krmpotic A, Bubic I, Polic B, Lucin P, Jonjic S. Pathogenesis of murine cytomegalovirus infection. Microbes Infect (2003) 5(13):1263-77. doi:10.1016/j. micinf.2003.09.007

29. Volkmer H, Bertholet C, Jonjic S, Wittek R, Koszinowski UH. Cytolytic $\mathrm{T}$ lymphocyte recognition of the murine cytomegalovirus nonstructural immediate-early protein pp89 expressed by recombinant vaccinia virus. J Exp Med (1987) 166(3):668-77. doi:10.1084/jem.166.3.668

30. Battegay M, Cooper S, Althage A, Banziger J, Hengartner H, Zinkernagel RM. Quantification of lymphocytic choriomeningitis virus with an immunological focus assay in 24- or 96-well plates. J Virol Methods (1991) 33(1-2):191-8. doi:10.1016/0166-0934(91)90018-U

31. van Aalderen MC, Remmerswaal EB, Verstegen NJ, Hombrink P, ten Brinke A, Pircher $\mathrm{H}$, et al. Infection history determines the differentiation state of human CD8+ T cells. J Virol (2015) 89(9):5110-23. doi:10.1128/JVI. 03478-14

32. Boom R, Sol C, Weel J, Gerrits Y, de Boer M, Wertheim-van Dillen P. A highly sensitive assay for detection and quantitation of human cytomegalovirus DNA in serum and plasma by PCR and electrochemiluminescence. J Clin Microbiol (1999) 37(5):1489-97.

33. Arens R, Loewendorf A, Redeker A, Sierro S, Boon L, Klenerman P, et al. Differential B7-CD28 costimulatory requirements for stable and inflationary mouse cytomegalovirus-specific memory CD8 T cell populations. J Immunol (2011) 186(7):3874-81. doi:10.4049/jimmunol.1003231

34. Hollt T, Pezzotti N, van Unen V, Koning F, Eisemann E, Lelieveldt B, et al. Cytosplore: interactive immune cell phenotyping for large single-cell datasets. Comput Graph Forum (2016) 35(3):171-80. doi:10.1111/cgf.12893

35. Arens R, Wang P, Sidney J, Loewendorf A, Sette A, Schoenberger SP, et al. Cutting edge: murine cytomegalovirus induces a polyfunctional CD4 T cell response. J Immunol (2008) 180(10):6472-6. doi:10.4049/jimmunol.180. 10.6472

36. Strindhall J, Skog M, Ernerudh J, Bengner M, Lofgren S, Matussek A, et al. The inverted CD4/CD8 ratio and associated parameters in 66-year-old individuals: the Swedish HEXA immune study. Age (2013) 35(3):985-91. doi:10.1007/s11357-012-9400-3

37. Pezzotti N, Lelieveldt BPF, van der Maaten L, Hollt T, Eisemann E, Vilanova A. Approximated and user steerable tSNE for progressive visual analytics. IEEE Trans Vis Comput Graph (2017) 23(7):1739-52. doi:10.1109/ Trcg.2016.2570755

38. Ferrando-Martinez S, Ruiz-Mateos E, Casazza JP, de Pablo-Bernal RS, Dominguez-Molina B, Munoz-Fernandez MA, et al. IFNgamma(-) TNFalpha(-)IL2(-)MIP1alpha(-)CD107a(+)PRF1(+) CD8 pp65-specific T-cell response is independently associated with time to death in elderly humans. J Gerontol A Biol Sci Med Sci (2015) 70(10):1210-8. doi:10.1093/ gerona/glu171
39. Ross SA, Arora N, Novak Z, Fowler KB, Britt WJ, Boppana SB. Cytomegalovirus reinfections in healthy seroimmune women. J Infect Dis (2010) 201(3):386-9. doi:10.1086/649903

40. O’Connor D, Truck J, Lazarus R, Clutterbuck EA, Voysey M, Jeffery K, et al. The effect of chronic cytomegalovirus infection on pneumococcal vaccine responses. J Infect Dis (2014) 209(10):1635-41. doi:10.1093/infdis/jit673

41. McElhaney JE, Garneau H, Camous X, Dupuis G, Pawelec G, Baehl S, et al. Predictors of the antibody response to influenza vaccination in older adults with type 2 diabetes. BMJ Open Diabetes Res Care (2015) 3(1):e000140. doi:10.1136/bmjdrc-2015-000140

42. Haq K, Fulop T, Tedder G, Gentleman B, Garneau H, Meneilly GS, et al. Cytomegalovirus seropositivity predicts a decline in the $\mathrm{T}$ cell but not the antibody response to influenza in vaccinated older adults independent of type 2 diabetes status. J Gerontol A Biol Sci Med Sci (2017) 72(9):1163-70. doi:10.1093/gerona/glw216

43. Weltevrede M, Eilers R, de Melker HE, van Baarle D. Cytomegalovirus persistence and T-cell immunosenescence in people aged fifty and older: A systematic review. Exp Gerontol (2016) 77:87-95. doi:10.1016/j.exger.2016. 02.005

44. Turner JE, Campbell JP, Edwards KM, Howarth LJ, Pawelec G, Aldred S, et al. Rudimentary signs of immunosenescence in Cytomegalovirusseropositive healthy young adults. Age (2014) 36(1):287-97. doi:10.1007/ s11357-013-9557-4

45. Reddehase MJ, Balthesen M, Rapp M, Jonjic S, Pavic I, Koszinowski UH. The conditions of primary infection define the load of latent viral genome in organs and the risk of recurrent cytomegalovirus disease. J Exp Med (1994) 179(1):185-93. doi:10.1084/jem.179.1.185

46. Briceno O, Lissina A, Wanke K, Afonso G, von Braun A, Ragon K, et al. Reduced naive CD8(+) T-cell priming efficacy in elderly adults. Aging Cell (2016) 15(1):14-21. doi:10.1111/acel.12384

47. Welten SP, Redeker A, Toes RE, Arens R. Viral persistence induces antibody inflation without altering antibody avidity. J Virol (2016) 90(9):4402-11. doi:10.1128/JVI.03177-15

48. Parry HM, Zuo J, Frumento G, Mirajkar N, Inman C, Edwards E, et al. Cytomegalovirus viral load within blood increases markedly in healthy people over the age of 70 years. Immun Ageing (2016) 13:1. doi:10.1186/ s12979-015-0056-6

49. Barton ES, White DW, Cathelyn JS, Brett-McClellan KA, Engle M, Diamond MS, et al. Herpesvirus latency confers symbiotic protection from bacterial infection. Nature (2007) 447(7142):326-9. doi:10.1038/nature05762

50. Yager EJ, Szaba FM, Kummer LW, Lanzer KG, Burkum CE, Smiley ST, et al. gamma-Herpesvirus-induced protection against bacterial infection is transient. Viral Immunol (2009) 22(1):67-72. doi:10.1089/vim.2008.0086

Conflict of Interest Statement: The authors declare that the research was conducted in the absence of any commercial or financial relationships that could be construed as a potential conflict of interest.

Copyright (C) 2018 Redeker, Remmerswaal, van der Gracht, Welten, Höllt, Koning, Cicin-Sain, Nikolich-Žugich, ten Berge, van Lier, van Unen and Arens. This is an open-access article distributed under the terms of the Creative Commons Attribution License (CC BY). The use, distribution or reproduction in other forums is permitted, provided the original author(s) or licensor are credited and that the original publication in this journal is cited, in accordance with accepted academic practice. No use, distribution or reproduction is permitted which does not comply with these terms. 